\title{
Plotinus on the Making of Matter Part II: 'A Corpse Adorned' (Enn. II 4 [12] 5.18)
}

\author{
Denis O'Brien \\ Centre National de la Recherche Scientifique, Paris, France \\ Plotinus@wanadoo.fr
}

\begin{abstract}
Soul springs from Intellect, Intellect springs from the One. But quite how does the sensible world arise? A pair of almost successive treatises (III 9 [13] 3 and III 4 [15] 1) points to the answer. A lower manifestation of soul 'makes' or 'gives birth to' what is variously described as 'non-being', 'utterly indefinite' and 'utterly dark', before covering what she has made with form, specifically the form of 'body', and before 'entering rejoicing' into the object that, by its reception of form, has been made ready to receive her and that, as the 'dwelling place' of soul, will be none other than the visible cosmos. A pair of earlier, again almost successive treatises, spells out the implication. The matter of the sensible world, covered with at least a minimum of form, is described as a 'corpse adorned' (II 4 [12] 5). The same object, but prior to its 'adornment', prior therefore to its appearance as a 'body' that is a 'corpse', and prior to any 'indwelling' of soul, is specifically said to be 'non-being' and the 'darkness of matter' (V 1 [10] 2), a transparent allusion to the product of soul in the two later treatises. The soul's making of 'darkness', so we may infer, is a making of 'matter', the final act in the drama by which everything that exists, including the material substrate of the world we see and feel around us, stems ultimately from the One.
\end{abstract}

\section{Keywords}

soul, matter, body, darkness, 'the last of things above', 'the last of what is below' (Enn. III 4 [15] 1.16-17), logos and alogos, Proclus' 'demiurgic' makings, image and allegory

At this point, I can well believe that Phillips would prefer to let drop the lines quoted from On contemplation, and hurry on to one or other of all 
the many remaining quotations still piled up against me on the last full page but one of his article-keeping his fingers crossed, and hoping for better luck next time. ${ }^{1}$

But I think it is more salutary to pause, and to ask why it is that, in choosing to include in his rag-bag of quotations bits and bobs taken from the sentences he has spent so much time on in the preceding pages of his article, Phillips has failed to see a point that has only to be stated to be obvious: without some very fancy footwork, which Phillips has not even attempted to engage in, one and the same thing cannot be, at the same time, both $\lambda$ óros and $\ddot{\alpha} \lambda$ oros. ${ }^{2}$

How has Phillips been led to overlook that simple point? The error is not, I think, merely the error of anyone attempting to make sense of the philosophy of the Enneads by working from an inventory of short quotations, stacked together regardless of the context from which each one has been taken. Phillips' failing to notice the all-too-obvious contradiction thrown up by his attempted assimilation of the two passages (from Various investigations and from On contemplation) betrays, I suspect, lack of familiarity with two other places in the Enneads where, as in the sentences quoted from On contemplation, the sensible world, or some part of it, is compared to a 'corpse'.

In all three passages, as we shall see, Plotinus aims to illustrate the nature of an object that, though lacking life and in that sense a 'corpse', is not therefore wholly below the level of form. That distinction, common to all three texts, will put in its proper perspective the relationship between the product of a partial soul in Various investigations, specifically said to be alogos, and the 'corpse-like' logos of On contemplation. The relationship is not at all, as Phillips has all too glibly supposed it to be, one of identity. ${ }^{3}$

1) The text in question: On contemplation, Enn. III 8 [30] 2.23-34. See $\$ 5$ above. The 'remaining quotations': see Phillips, 2009, 134. Cf. $\$ 4$ above. In these opening paragraphs, I pick up from where my earlier article left off. See 'Plotinus on the Making of Matter: Part I: The Identity of Darkness', published in the preceding issue of this Journal.

2) Phillips, 2009, 134, seeks to identify the 'corpse-like' logos of On contemplation, Enn. III 8 [30] 2.23-34, with the product of a partial soul, specifically said to be alogos, in Various investigations, Enn. III 9 [13] 3. See $\$ \$ 11$ and 12 above.

3) Plotinus introduces the image of a corpse in the following three texts, in the chronological order of composition: On the three principal hypostases, Enn. V 1 [10] 2.1-27 (see

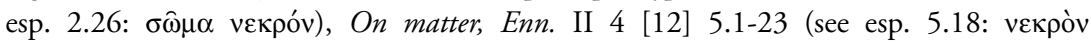

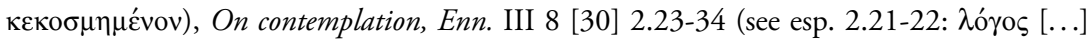




\section{$\$$ 13. The 'Corpse' and Its 'Adornment' (Enn. II 4 [12] 5) ${ }^{4}$}

\section{'Living' matter and a 'corpse adorned'}

In his account of 'the two matters', the title that Porphyry originally chose for the treatise eventually to become the fourth tractate of the second Ennead, the conjunction of matter and form in the sensible world is contrasted with the union of matter and form in the intelligible realm by being called a

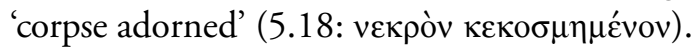

The context spells out in eloquent detail what Plotinus means by the metaphor. ${ }^{5}$ Matter is the 'darkness' underlying the light that is form, in the intelligible as in the sensible world, but with the difference, the crucial difference, that in the intelligible world matter is able to take hold of form in such a way as to acquire a 'life, defined and intelligent' (5.16), whereas the matter of the sensible world, although by the presence of form it 'becomes something definite' (5.17), has in itself neither life nor intelligence, and is for that reason, even when form has been added to it, no more than a 'corpse adorned' (5.18).

The 'corpse adorned', contrary to what a casual reading of the metaphor might lead us to suppose, is therefore not simply matter, but matter as already covered by form. It is a 'corpse', because it is not 'alive' (5.19: ov̉ $\mu \eta ̀ v ~ \zeta \hat{\omega} v)$, but a corpse 'adorned' because it is already 'something defi-

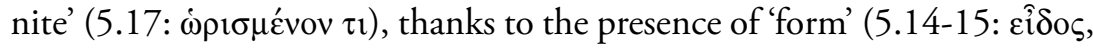

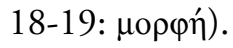

\section{Comparisons, true and false}

The use that Plotinus will make of the same metaphor some time later, probably some years later, in On contemplation, will not be quite the same. ${ }^{6}$

\footnotetext{
veкрós). For the attempted identification of the 'corpse-like' logos of On contemplation with the product of a partial soul in Various investigations, Enn. III 9 [13] 3, see again Phillips, 2009, 134.

4) The numbering of the sections picks up from 'Plotinus on the Making of Matter: Part I: The Identity of Darkness'.

5) The paragraph that follows is a summary of Enn. II 4 [12] 5.

6) On matter, Enn. II 4 [12], was one of the 21 tractates composed before Porphyry's arrival in Rome (cf. $\$ 4$ above). On contemplation (Enn. III 8 [30]) falls roughly mid-way in the treatises (numbered 22 to 43 ) that Porphyry says were written in the six-year period that he
} 
The 'corpse' of On contemplation is a logos associated with 'visible form', very likely the 'visible form' that physis, the parent of the corpse-like logos, 'gives' to the substrate in which her offspring finds itself.7 Despite the difference, the two treatises, On matter and On contemplation, are at one in associating the 'corpse' with talk of a substrate only when the substrate has been covered by 'form' (in both places $\mu о \rho \varphi \eta$ ), with the additional qualification, in On contemplation, that the form in question is 'visible form', and with the additional qualification, in $O n$ matter, that the corpse in question is a 'corpse adorned'. The 'adornment' of the corpse of this world, so we may well conclude, is none other than, or is at least included in, 'visible form', the shapes and colours that conceal, though they do not do away with, the darkness and formlessness of matter. ${ }^{8}$

The two uses of the metaphor of a 'corpse', in On matter and in $O n$ contemplation, point to Phillips' elementary error in thinking that the corpse-like logos of On contemplation may be compared with the product said to be alogos in Various investigations. Phillips has failed to see the clash between logos and alogos at least in part because he has taken no account of the description of the 'corpse adorned' in the treatise On matter, and has therefore failed to distinguish two quite different 'makings', the 'making' by physis of a corpse-like logos in On contemplation (2.29: $\pi$ oteî) and the 'making' by a partial soul of an 'image' of herself, specifically said to be alogos, in Various investigations (3.10: again $\pi \mathrm{or \varepsilon î).}$

then spent in Plotinus' company (263-268 A.D.). See Vita 5, and Richard Goulet's commentary (1982).

7) On contemplation, Enn. III 8 [30] 2.28-34, see $\$ 5$ above. For the divergence, between Philips and myself, on the identity of the 'giver' (whether physis or the 'offspring' of physis), see $\$ \$ 6$ and 7 above.

8) The two passages compared here are On matter, Enn. II 4 [12] 5.1-23, and On contemplation, Enn. III 8 [30] 2.28-34. For the notion of 'concealment', a major preoccupation of Plotinus' 'theodicy', see, for example, the closing sentences of the treatise On what evils are and where they come from (Enn. I 8 [51] 15.24-28): matter, both ugliness and evil, has to be veiled from the sight of the higher realities. Cf. O'Brien, 1993, 42-49. In that same treatise, one of Plotinus' last attempts at producing a sustained argument on a major theme, the notion of 'adornment' recurs when the object that will prove to be matter is spoken of as

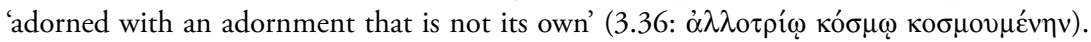
The 'adornment' is here specified as 'shapes and forms and measures and limits' (1.35-36:

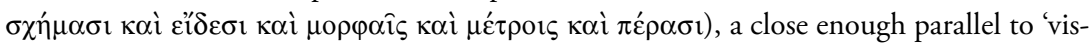

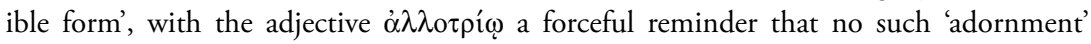
belongs to matter as of right. 
The verb in the two texts may be the same (in both texts $\pi$ oteî). The subject of the verb, whether or not the same, is in either case a psychic power (a 'partial soul' in Various investigations, physis in On contemplation). But it does not at all follow, as Phillips thinks it does, that the object that is 'made', alogos in one text (Various investigations), logos in the other (On contemplation), is therefore also the same. The difference will be at once obvious if we return to the description of the 'corpse adorned' in the treatise On matter. ${ }^{9}$

\section{An impossible identification}

The 'image' produced by a partial soul in Various investigations, described as 'non-being' and as 'utterly dark', cannot be identified with the 'corpse' of On matter, since this is matter that has already been covered with at least minimal form and is, for that very reason, a 'corpse adorned'. Still less therefore can it be identified, as Phillips thinks it can be, with the 'corpselike' logos of On contemplation, bearer of, if not identical to, 'visible form', the 'visible form' that in all likelihood provides the 'adornment' of the 'corpse adorned'. ${ }^{10}$ The 'adornment' is precisely what is lacking in the object described as 'non-being' and 'utterly dark', the 'image' produced by a 'partial soul' in Various investigations, before it has been covered by form as a result of the soul's 'second' initiative.

Were we to adopt Phillips' identification of the 'image' produced by a partial soul in Various investigations with the corpse-like logos of On contemplation, we should have to suppose that, when the partial soul, in Various investigations, 'saw again' the 'image' she had made and 'covered it with form' (3.16) by a 'second initiative' (3.15), she was bringing form to an object that already possessed what Phillips likes to call 'the tracesoul', and which he supposes to be none other than the 'visible form' of On contemplation. ${ }^{11}$

\footnotetext{
9) For neglect of the difference, see again Phillips, 2009, 134, where the corpse-like logos of On contemplation (2.28-34), is said to be none other than the product of the 'partial soul', specified as alogos in Various investigations (3.13).

10) See again Phillips, 2009, 134 (his identification of the corpse-like logos of On contemplation with the 'image' of Various investigations).

11) Phillips, 2009, 122-133 ('trace-soul' in general), 129 ('trace-soul' identified with 'visible form'). See also the list of comparisons on the penultimate full page of his article (p. 134).
} 
But when the soul 'makes' an 'image' of herself in Various investigations, as a result of what is by implication her 'first' initiative, there is not the slightest indication, in the text, that the 'image' she makes is already invested with 'visible form', prior to the soul's own subsequent action in 'covering with form' the image she has made.

If the 'image' that is 'made' by a partial soul were already covered by form, albeit by only a 'trace' of form, before the soul's 'second initiative', then how could such an image, with its covering of form, however minimal, possibly be said to be, not merely 'dark', but 'utterly dark'

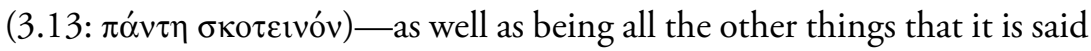

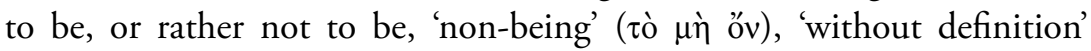

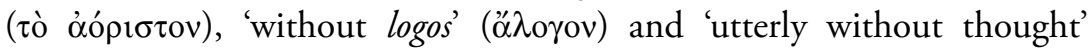

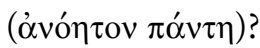

\section{The extended comparison}

To protest that the object made by a partial soul in Various investigations, even before it has been given form by the soul that made it, nonetheless already has a 'trace' of form, is to fly in the face of the obvious meaning of the words in the text. The object made by what is implied as having been the soul's 'first initiative' cannot possibly be identified with the 'corpse-like' logos of On contemplation, specifically associated with, if not indeed identical to, 'visible form', any more than it can possibly be identified outright with the 'corpse' of On matter since, although this is a 'corpse', it is a 'corpse adorned', a substrate therefore that has already received form enough to count as its 'adornment'.

That conclusion does not mean that the two passages, On contemplation and Various investigations, cannot be compared. The point is simply that, if we extend the metaphor of a 'corpse' in On contemplation to include the metaphor of a 'corpse' in the treatise On matter, and if we seek to find a place for that same metaphor in Plotinus' description of the product of a 'partial soul' in Various investigations, then the terms of the comparison cannot be what Phillips' thesis would require them to be when he asserts that the 'image' of soul in Various investigations is the same as the corpselike logos of On contemplation.

If what is 'utterly dark' (3.13) and 'non-being' (3.9 and 11) in Various investigations, the product of a partial soul before that same product 
has been covered by form, is to be found a place in the text quoted from On contemplation, it will have to be matched with the substrate before the substrate has received the 'visible form' that is, or that is associated with, the logos that is a 'corpse'.

Equally, if it is to be found a place in the treatise On matter, the 'image' of Various investigations (3.11 and 12) will have to be identified, not with the 'corpse adorned', but with the darkness of matter before it has been covered by what is presumably that same 'visible form' in order to become a 'corpse adorned'.

\section{The knell tolls}

Do I need to labour the point? Or has Phillips perhaps already seen the abyss that is opening up before him? Not only does the comparison that he has appealed to of the 'image' of Various investigations with the corpse-like logos of On contemplation not support his argument. The very text that Phillips has sought to quote against me tells in my favour.

If we take up the comparison that Phillips himself has appealed to, the comparison of what is said of a 'partial soul' and its 'image', in Various investigations, with what is said of physis and its 'offspring', the 'corpse-like' logos of On contemplation, and if we extend the comparison to include the metaphor of a 'corpse adorned' in the treatise On matter, then the conclusion we are led to is the very conclusion that Phillips has sought so sedulously to avoid.

When the soul of Various investigations 'makes' an 'image' of herself that is 'utterly dark', she does not make what is elsewhere referred to as a 'corpse', whether the 'corpse-like' logos of On contemplation or the 'corpse adorned' of the treatise On matter. When she 'makes' what is 'utterly dark', the darkness that she makes is none other than the substrate that is a recipient of the 'visible form' associated with the corpse-like logos of On contemplation, the 'darkness' therefore that is matter before it has been covered with visible form so as to become a 'corpse adorned', in the treatise On matter.

The conclusion is inescapable. What the image of the 'corpse' has to tell us, whether the 'corpse-like' logos of On contemplation or the 'corpse adorned' of $O n$ matter, is that, when the soul of Various investigations 'makes' what is 'utterly dark', the darkness that she makes is darkness prior 
to the reception of form, and very likely therefore the darkness that, in the treatise On matter, is specifically said to be the 'darkness' of matter. The knell tolls for Phillips' attempted refutation of my thesis. ${ }^{12}$

\section{S 14. 'The Darkness of Matter' (Enn. V 1 [10] 2)}

\section{The universe emptied of soul}

The conclusion to be drawn is no different, if we turn to Plotinus' earlier use of the metaphor of a 'corpse' in the treatise entitled by Porphyry On the three principal hypostases, the treatise next but one preceding Plotinus' analysis of matter and therefore much closer in time than the text from On contemplation to the account of 'partial soul' in Various investigations. ${ }^{13}$

In The three principal hypostases, Plotinus asks us to imagine the whole visible universe as it would be if emptied of soul (2.1-27). It would then,

12) I leave aside here the description of matter as an $\varepsilon$ ¿ $\delta \omega \lambda \mathrm{ov}$, in the text quoted from On matter (Enn. II 4 [12] 5.18-20). 'Form' and 'substrate' in the sensible world are both

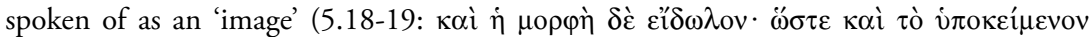
$\varepsilon$ ' $\delta \omega \lambda \mathrm{ov})$, in contradistinction to intelligible matter, where both 'form' and 'substrate' are

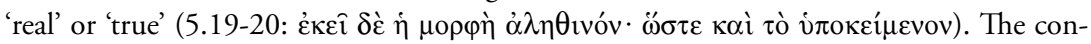

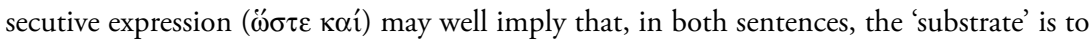
be thought of in conjunction with form. A form that is an 'image' cannot make her substrate (the matter of the sensible world) anything more than an 'image', whereas a form that it 'true' or 'real' makes of her substrate (the matter of the intelligible world) something that is also 'true' or 'real'. If that is so, then the substrate that is here said to be an 'image' is perhaps more likely to be, or to include, the 'corpse adorned', rather than applying exclusively to the object 'utterly dark' said to be an 'image' of soul in Various investigations. Whether or not that is so, there can be no straightforward one-to-one correlation between the 'image' of Various investigations (3.11 and 12: $\varepsilon 1 \delta \omega \lambda \mathrm{ov}$ ) and the 'image' of On matter (5.18-19: $\varepsilon$ ”i $\left.\delta \lambda_{\mathrm{ov}}\right)$, simply because, in the latter treatise, the same word serves as a description of both 'form' and 'substrate'.

13) The three texts are virtually successive: On the three principal hypostases is Enn. V 1 [10], On matter is Enn. II 4 [12], Various investigations is Enn. III 9 [13]. The intervening treatise, the eleventh in Porphyry's chronological ordering, On the generation and order of things that come after the first (Enn. V 2 [11]), has only two chapters, largely given over to establishing the nature of the soul whose activity will be described in detail in Enn. III 9 [13] 3 and Enn. III 4 [15] 1 (for the latter treatise, see $\$ 16$ below). These texts were all written before Porphyry's arrival in Rome. On contemplation, belongs to a much later group of treatises, composed in the years following Porphyry’s arrival. See above $\$ 13$. 
so he tells us, appear as no more than a 'dead body', a 'corpse' (2.26: $\sigma \hat{\omega} \mu \alpha$ vยкро́v), mere 'earth and water', until the moment comes for soul to take up her dwelling within the 'corpse' and to set it in motion (2.23-26).

The 'corpse' is here, as it will be in the treatise On matter, not a bare substrate, but matter that has already been partly covered by form, since it is specifically said to be 'earth and water', the two lower elements of the physical universe. In both texts, the 'corpse' is matter that, although lacking in life, is nonetheless covered sufficiently with form to qualify as a 'corpse adorned' (On matter) and to be identified with at least two of the elements that make up the world we live in (The three principal hypostases).

\section{The 'darkness of matter and non-being'}

That aspect of the metaphor is brought out all the more clearly in the continuation of the sentence from The three principal hypostases, when Plotinus asks us to shift, if only in our imagination, from the body that is a 'corpse' to matter that is entirely lacking in form. Deprived of soul, the whole ouranos would be nothing but 'dead body', a 'corpse', mere 'earth and water' (2.25-26); 'rather,' Plotinus continues, it would be the 'darkness of

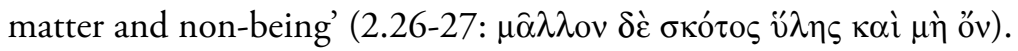

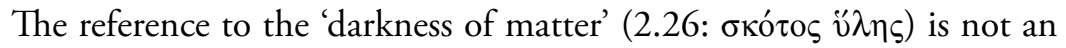
extension of the metaphor of the 'corpse', a 'corpse' that has already been said to be 'body' (cf. 2.26: $\sigma \hat{\omega} \mu \alpha$ vعкрóv). The 'darkness of matter and nonbeing' is the description of a more primitive substrate, matter before it has been covered by the form of 'body'. The shift from the 'body' that is a 'corpse' to the 'darkness of matter' is added by way of tightening the screw, as a surenchère (2.26: $\mu \hat{\alpha} \lambda \lambda$ ov $\delta \dot{\varepsilon} . .$.$) , aimed at bringing out all the more$ starkly the need for soul.

It is only thanks to the good offices of soul that the world we live in is not a 'corpse-like body', mere earth and water, still less the 'darkness of matter and non-being', a complete absence of form therefore. Neither bare matter nor inanimate body, the world around us, thanks to the presence of soul, is, as in Plato's Timaeus, 'a blissful, living being' (2.24). ${ }^{14}$

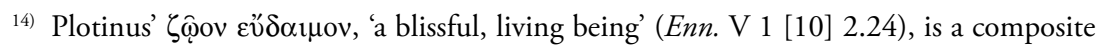
allusion to Plato's description in the Timaeus of the visible universe as a 'living being ensouled'

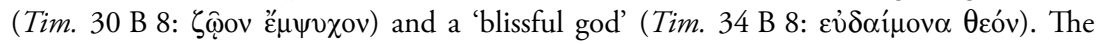
noun ( $\left.\zeta_{\omega} \mathrm{ov}\right)$ is taken from the first passage, the adjective from the second (with necessarily 


\section{The dwelling-place of soul}

In The three principal hypostases, we are therefore able to distinguish three successive strata in the structure of the visible cosmos. There is, first,

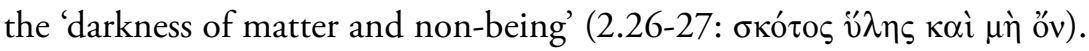
There is, secondly, the 'body of the heavens' (2.22: $\sigma \hat{\omega} \mu \alpha$ ov่pavov̂) when it is no longer mere 'darkness' and 'non-being', but already body, specifically the two lower elements, earth and water, even though a 'body' that, 'before' the arrival of 'soul', is a dead body, a 'corpse' (2.25-26: ڤ̂v $\pi \rho \grave{~}$

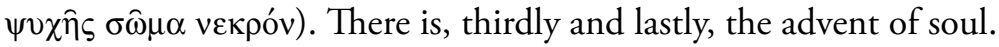

When we imagine soul as flowing back, 'entering into the body of the

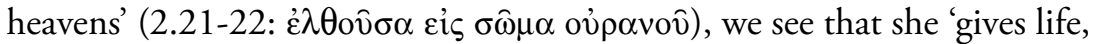
gives immortality' (cf. 2.21), 'rouses the body that is inert' (cf. 2.23: "i $\gamma \varepsilon \iota \rho \varepsilon$ $\delta \dot{\varepsilon} \kappa \varepsilon i ́ \mu \varepsilon v o v)$. The body of the world is set in motion with a motion that is 'everlasting', thanks to the soul that 'has taken up her dwelling within it'

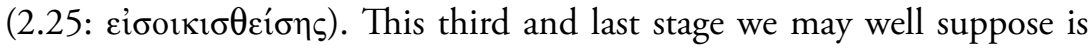
analogous to what we are told in Various investigations, where the soul is again shown as 'entering into' an object that has been 'covered with form'.

The verb is the same in the two texts. ${ }^{15}$ The soul that, in The three principal hypostases, will bring life and movement to the cosmos, herself 'enters into' the body of the ouranos in order to do so (2.21: $\dot{\varepsilon} \lambda \theta 0 \hat{\sigma} \sigma \alpha)$. In Various investigations, the partial soul 'enters, rejoicing' into the image that she has made (3.16: "̌ $p \chi \varepsilon \tau \alpha \mathrm{l})$. In both texts, darkness, once it has been raised to the level of 'body' (The three principal hypostases), 'covered with form' (Various investigations), will provide a suitable harbour for the 'entry' of soul.

\section{The formation of the cosmos}

But that is not the only point of comparison between the two texts. All three stages in the formation of the cosmos, clearly delineated in The three

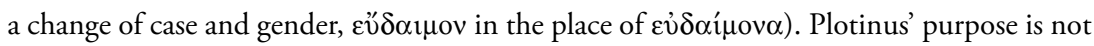
to deny that the cosmos is divine. His aim is to emphasise that both its life (2.23-24) and its divinity (2.38-40) are due to the presence of soul, with the 'living being' that is the cosmos (cf. 2.24: $\zeta$ $\mathrm{ov}_{\mathrm{ov}}$ ) therefore contrasted, in the continuation of the same sentence, to the body that, in the absence of soul, can be no more than a 'corpse' (cf. 2.26: $\sigma \omega \hat{\omega} \mu \alpha$ veкрóv).

15) The two texts compared here are On the three principal hypostases, Enn. V 1 [10] 2, and Various investigations, Enn. III 9 [13] 3. 
principal hypostases, are to be found, no less clearly set out, and with much the same wording, in Various investigations. ${ }^{16}$

In Various investigations, there is, first, the product that is 'utterly dark'

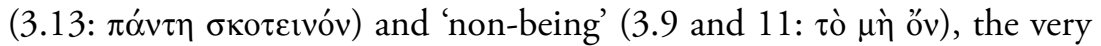
words that appear in The three principal hypostases, where, prior to soul and even prior to body, there is the 'darkness of matter and non-being'

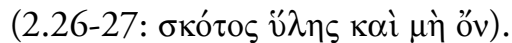

There is secondly, in Various investigations, the moment when this same

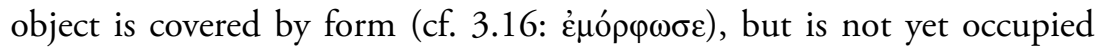
by soul, and may therefore be compared to the 'body', specifically earth and water, that 'prior to soul' is a 'corpse', in The three principal hypostases

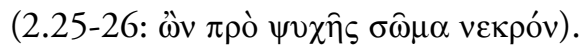

Only then, thirdly and lastly, are we told, in Various investigations, of the

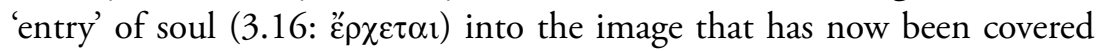
with form, the same verb that, in The three principal hypostases, describes the 'entry' of soul 'into the body of the universe' (2.21-22: '̇ $\lambda \theta 0 \hat{\sigma} \sigma \alpha$ cis

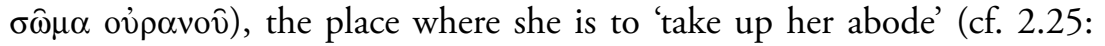

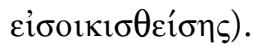

\section{The missing detail}

The similarity of structure and wording is unmistakable. But the parallelism is deficient in one crucial respect. In each of the two texts, there is one detail that is missing, and that is provided by the other text in the pair.

In Various investigations, we are not told, specifically, that what is 'utterly

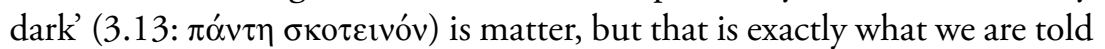
in The three principal hypostases, where what I have labelled the first and lowest stage is explicitly said to be, not merely 'darkness' and 'non-being', but the 'darkness of matter' (2.26: $\sigma \kappa o ́ \tau o \varsigma ~ u ̈ \lambda \eta \varsigma)$. Conversely, we are not told of the 'darkness of matter', in The three principal hypostases, as we are told of what is 'utterly dark', in Various investigations, that it is the product of soul (cf. 3.10: $\pi$ orعî).

However, we have only to put those two details together for the picture to be complete. The 'non-being', 'utterly dark', that the soul 'makes', in Various investigations, will be none other than the 'non-being' and the

16) Again, the two texts compared in the paragraphs that follow are On the three principal hypostases, Enn. V 1 [10] 2, and Various investigations, Enn. III 9 [13] 3. 
'darkness of matter' that Plotinus speaks of in The three principal hypostases. The degree of 'interpretation' is minimal. The conclusion is, to my mind, overwhelmingly probable.

If so, then the knell tolls again for Phillips' attempted refutation of my thesis. In two almost successive tractates, the reference is almost certainly the same. The 'darkness of matter', in The three principal hypostases, is in all likelihood none other than the darkness that the soul 'makes', in Various investigations.

\section{$\$$ 15. The 'Three Corpses'}

So much for the three treatises where Plotinus writes of the sensible world as a 'corpse', The three principal hypostases, On matter and On contemplation..$^{17}$ The repeated use of word and image, in all three treatises, shows clearly that the 'corpse-like' logos of On contemplation cannot be compared, as Phillips wishes it to be, with the product of a 'partial soul', specifically spoken of as alogos in Various investigations.

The truth is significantly different. The comparison of the 'body' that is a 'corpse', in The three principal hypostases, with the 'corpse adorned', in the treatise On matter, shows, unmistakably, that the 'image' produced by a 'partial soul' in Various investigations, 'utterly dark' and 'indefinite', if it is to be included in the same set of ideas, will have to be compared, not directly with the 'corpse', but with the 'darkness of matter' before it has been raised to the level of a 'body' that is a 'corpse' (The three principal hypostases), with 'matter' and with 'darkness' before it has been made a 'corpse adorned' (On matter), and therefore with the substrate before it has been given the 'visible form' associated with, or identical to, the 'corpselike' logos of On contemplation.

Carried away by his undisciplined talk of a 'trace-soul', Phillips has run together two quite different features characterising the relationship of soul to the sensible world and to matter in the philosophy of the Enneads. The three 'corpses' do indeed represent the sensible world, either as deprived of life and intelligence, but with a minimal covering of form (On matter),

\footnotetext{
17) See again On the three principal hypostases, Enn. V 1 [10] 2.1-27 (esp. 2.26: $\sigma \omega \hat{\omega} \mu \alpha$

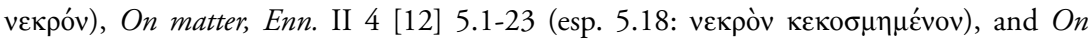

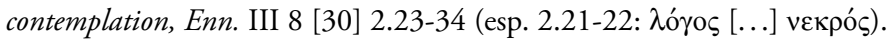


or as it would be if it were deprived of the living presence of soul (The three principal hypostases), or as a projection of physis that, although a logos, is a logos that is itself no longer living (On contemplation). But the three 'corpses' do not therefore correspond to the lowest level of the material world. Beneath the 'corpse adorned' of the treatise On matter, beneath the 'corpselike body', earth and water, of The three principal hypostases, and entirely distinct therefore from the 'corpse-like' logos that is, or that is associated with, 'visible form' in On contemplation, there lies the 'darkness' and the 'non-being' that is matter.

The 'darkness' and the 'non-being' specifically said to be matter in The three principal hypostases will in all likelihood be none other than the object spoken of as 'utterly dark' and 'non-being', made by a partial soul in Various investigations. In both treatises, the object spoken of as 'dark' or as 'darkness' and as 'non-being' will be matter prior to its reception of form, and prior therefore to the presence of soul, who takes up her abode in the sensible world only when matter has been at least partly covered with form and has therefore been made ready to receive her.

\section{$\$$ 16. The Soul 'in Plants' (Enn. III 4 [15] 1)}

\section{'On the daimon'}

In the light of that preliminary conclusion, I venture to add to the dossier one more text, where there is no mention of a 'corpse', but where the wording is so close to the wording of Various investigations that either treatise can be called upon to complement the other. This additional text is drawn from $O n$ the daimon who has taken charge of us, a treatise that follows almost immediately after Various investigations, and therefore soon after Plotinus' treatise On matter. ${ }^{18}$

Here, as in the comparison of The three principal hypostases, On matter and Various investigations ( $\$ 14$ above), I stress the chronological proximity, not in order to suggest any significant inconsistency in writings that are

\footnotetext{
18) On the daimon who has taken charge of us, Enn. III 4 [15], is preceded by Enn. II 2 [14], On the movement of the heavens, a short text of only three chapters, and otherwise follows on directly from Various investigations, Enn. III 9 [13], and On matter, Enn. II 4 [12].
} 
not contemporaneous, but simply because Plotinus' preoccupations are very obviously the same or similar at certain times of his life.

Tractates written at roughly the same time often show, as they will do here, a clear affinity of both content and language, and lend themselves therefore to cross-referencing, and to the possibility of reciprocal explanation, in a way that is much less arbitrary than if we simply pick out isolated words and expressions from tractates written after a lapse of some yearsas Phillips has so very obviously done on the penultimate full page of his article, where he juxtaposes quotations taken from the whole gamut of Plotinus' writings, seemingly taking no account, as he does so, of their chronological grouping.

\section{The soul that 'comes to be in plants'}

The continuity of interest, when we pass from Various investigations to On the daimon, is immediately apparent in the opening lines of the treatise, where Plotinus asks, disbelievingly, of the soul that 'comes to be in

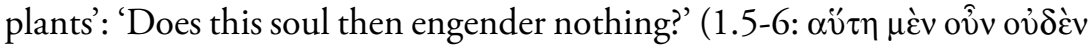
$\gamma \varepsilon v v \alpha \hat{\alpha}$;) He answers his own question: 'Oh but she does, she engenders

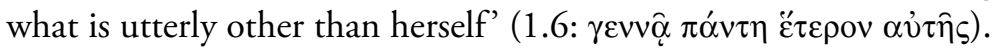

The tone of question and answer is as I have presented it. The note of 'disbelief' in the question matches what Denniston categorises as the 'adversative' use of the two particles (1.6: $\mu$ غ̀v oûv). ${ }^{19}$ In the preceding sentence, Plotinus has spoken of a higher manifestation of soul that generates

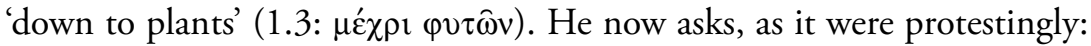
'You don't mean to tell me that, when she has got as far as plants (cf. 1.4-5:

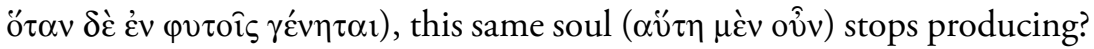

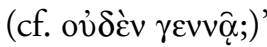

Denniston initially marks the 'adversative' use of the two particles ( $\mu \grave{\varepsilon} \nu$ o $v$ ) as 'very rare in continuous prose', and 'common' in dialogue. ${ }^{20}$ But in the following pages of his analysis, Denniston sets up a specific rubric for times when 'The speaker objects to his own words, virtually carrying on a dialogue with himself' ${ }^{21}$ This exactly matches the context in Plotinus. Here, as so often elsewhere, the style of the Enneads answers

\footnotetext{
19) Denniston, 1966, 475.

20) Denniston, 1966, 475.

21) Denniston, 1966, 478-479.
} 
perfectly to the definition of 'thinking' that Socrates is made to give in the Theaetetus. What is thinking? It is 'the soul herself asking herself questions and answering them, whether by saying "yes" or by saying "no"'.22

The implication marked by 'oh but' in my paraphrase of the answer is conveyed by the last word in the question, preceded by a negation

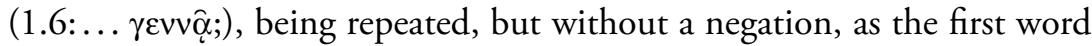
in the answer that follows ( $\gamma \varepsilon v v \hat{\alpha} \ldots . .$.$) . 'When she's got as far as plants, she$ doesn't still generate?' 'Oh but she does... ${ }^{23}$

\section{'Utterly lacking in definition'}

The description of what the soul 'engenders' or 'gives birth to' in On the daimon proves to be an extended analysis of the same 'lack of definition' that had already been marked out as one of the characteristics of the object made by a partial soul in Various investigations. The partial soul of Various investigations 'makes' (3.10: $\pi \mathrm{ot \varepsilon} \hat{\imath})$ 'what is lacking in definition'

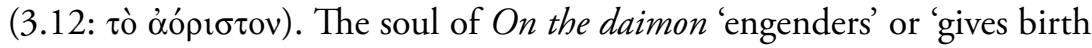

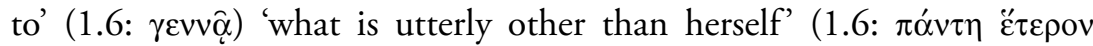

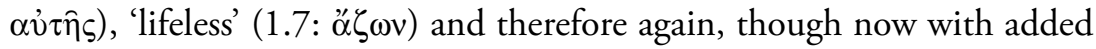

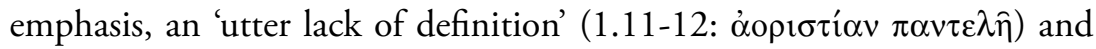

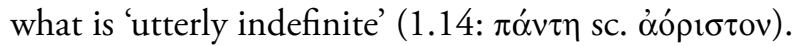

The successive negations of the opening chapter of $O n$ the daimon are designed to bring out a difference between the object brought to birth by

22) Cf. Theaetetus 189 E 6-190 A 2.

23) In quoting Denniston, I do of course recognise that his survey of Greek usage extends only to 320 B.C. (see Denniston, 1966, vii). The commoner uses catalogued by Denniston can nonetheless still be heard in the Greek of the Enneads. The ravishing variety and subtlety to be found in the play of particles in Plato's dialogues has of course long since died out. But some of the earlier distinctions are still plainly present. So it is that the 'adversative'

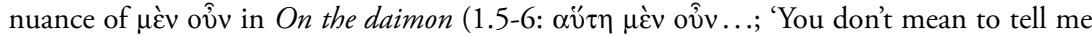
that this same soul...?') is, to my ear, clearly different from the use of the same two particles in the passage quoted earlier from On contemplation (Enn. III 8 [30] 2), where the meaning matches the use categorised by Denniston as 'transitional' (2.30-31: ó $\mu \grave{\varepsilon} v$ oủv $\lambda o ́$ ' 'So it is that ...', see $\$ 8$ above). Having introduced the first logos and its 'offspring', Plotinus goes on to specify the difference between the two (the first logos produces the second, but the second logos, the logos that is a 'corpse', cannot do as its parent had done, and cannot produce another logos in its turn). A systematic study of Plotinus' use of particles would be more than welcome. Any bright young thing who might think of taking up such a suggestion will have to hand an excellent model of how to tackle the project in Des Places (1929). 
the soul that 'comes to be in plants' and the realities that have appeared up to that moment in Plotinus' scheme of emanation. ${ }^{24}$ The difference lies in the point that, for all the higher reaches of emanation, the object 'engendered', although at first 'formless' (1.8: $\alpha$ ํóp $\varphi \omega \tau o v)$, was able to 'acquire

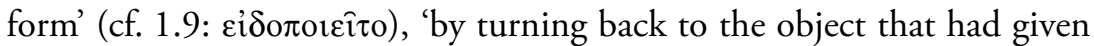

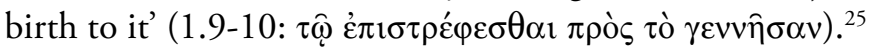

Not so what is brought to birth by the soul that 'comes to be in plants'. The object now in question, since it is 'no longer a kind of soul'

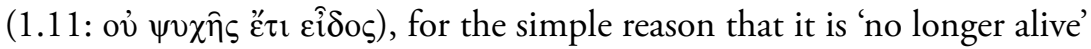

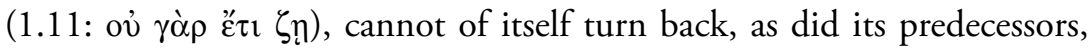
to what it was born from. Lifeless, it is also helpless, unable of itself to turn back to the principle from which it was born and unable therefore to acquire, by any effort of its own, whatever form or 'definition' might be suited to it.

Its lack of definition therefore no longer lies, as it did for the objects born before it, in a lack of definition relating only to the 'completion'

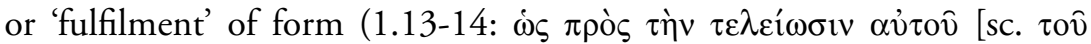

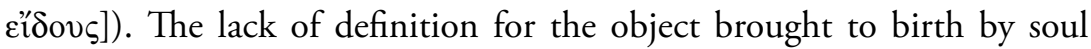
when she 'comes to be in plants' is a total lack. It is 'what is utterly other

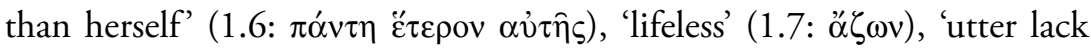
of definition' (1.11-12: $\alpha$ op $\sigma \tau i \alpha v \pi \alpha v \tau \varepsilon \lambda \hat{\eta})$ and 'utterly indefinite' (1.14:

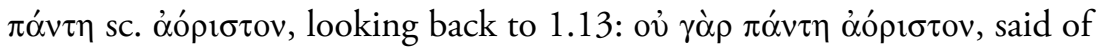
the higher realities).

\section{$\$ 17$. 'Utterly Dark' and 'Utterly Indefinite'}

In his account of the object brought to birth by soul in On the daimon, Plotinus' heavy-handed repetition of adverb and adjective ( $\pi$ óv $\tau \eta$ three times, $\pi \alpha v \tau \varepsilon \lambda \hat{\eta}$ once) makes one point unmistakably clear. Whatever it may be, the object in question, 'utter indefiniteness' (1.11-12) and 'utterly indefinite' (1.14), cannot be the same as the 'corpse adorned' of the treatise On matter, since in virtue of its 'adornment', the 'corpse adorned' was

\footnotetext{
24) This and the two paragraphs that follow summarise Enn. III 4 [15] 1.7-14.

25) For the production of Soul and Intellect, each of them acquiring form and definition by 'looking back' or 'turning back' to its source, Intellect to the One, Soul to Intellect, see the selection of texts translated and commented upon in O'Brien, 2005, 63-70.
} 


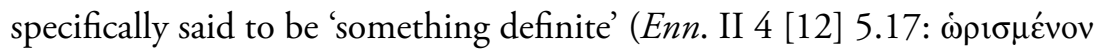
$\tau \imath)$. But does not that very disparity carry with it a tacit affirmation? If we deprive the 'corpse' of its 'adornment', and therefore of its 'definition', what can be left but matter, unadorned and undefined?

Read in the light of that simple distinction, what Plotinus tells us in On the daimon is essentially the same as what he tells us in Various investigations. In Various investigations, the product of a partial soul is 'what is

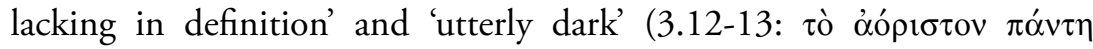

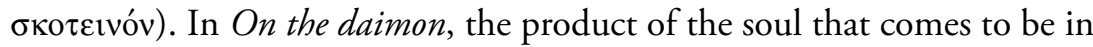

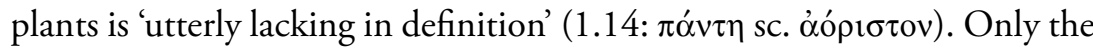
placing of the adverb ( $\pi \alpha \dot{v} v \eta)$ has changed. The reference of the expression will be, in both texts, the same. ${ }^{26}$

If, as seems more than likely, what is 'utterly dark' (Various investigations) is nothing other than the 'darkness of matter' before it has been made into the 'corpse-like' body of 'earth and water', prior to the advent of soul (The three principal hypostases), and therefore matter before it has acquired the modicum of 'definition' needed for the 'darkness' of matter to appear as a 'corpse adorned' (On matter), then the same will, in all probability, be true of what is 'utterly lacking in definition' (On the daimon). ${ }^{27}$

The object 'utterly lacking in definition', in On the daimon (1.14: $\pi$ óv

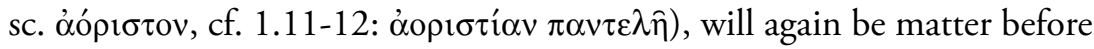
it has been given the 'visible form' identical to, or associated with, a logos that is a 'corpse' (On contemplation), and once again therefore matter before it has acquired the degree of 'definition' (cf. 5.17: $\dot{\omega} \rho ı \mu \varepsilon \dot{\varepsilon} v o v \tau \imath$ ) needed to qualify as a 'corpse adorned' (On matter).$^{28}$

26) Has even the placing of the adverb changed? In the first quotation, from Various inves-

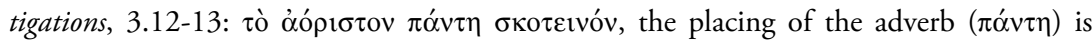

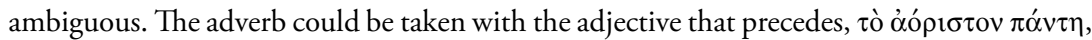

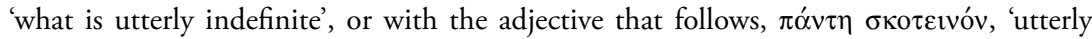
dark'. I have chosen the second syntax, partly because it seems to me slightly more probable, and partly to avoid any accusation of special pleading, were I to claim an exact parallel

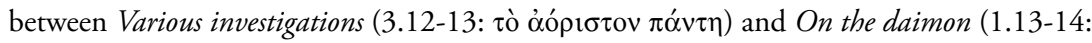

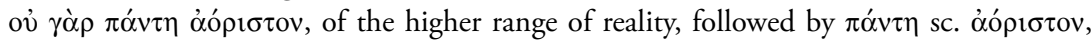
'utterly indefinite', for the object brought to birth by soul).

27) For the comparison of Various investigations, Enn. III 9 [13] 3, with the treatise On matter, Enn. II 2 [14] 5, see $\$ 13$ above. For the comparison with The three principal hypostases, Enn. V 1 [10] 2, see $\$ 14$ above.

28) The three texts compared are On the daimon, Enn. III 4 [15] 1, On contemplation, 
The product of soul in $O n$ the daimon, so we may well suppose, will be no different from the product of soul in Various investigations. In both texts, what issues from soul will be matter, 'utterly dark' and 'undefined' (Various investigations), an 'utter lack of definition' and 'utterly undefined' (On the daimon). If that is so, our quest is at an end. The soul 'makes' matter in Various investigations. The soul 'gives birth' to matter in On the daimon. ${ }^{29}$

\section{$\$$ 18. Impossible Comparisons}

\section{A wearisome return?}

Is it too wearisome to return at this point, however briefly, to Phillips' counter-thesis? The identity of the two objects, the one 'brought to birth' by soul 'when she comes to be in plants', in On the daimon, the other, the object that is 'made' by a 'partial soul', in Various investigations, is a prominent feature of the thesis that Phillips seeks to overthrow, as is also the conclusion that, in both treatises, the product of soul is none other than matter. ${ }^{30}$

To establish clear blue water between that thesis and his own counterthesis, Phillips allows that the product of soul in the two treatises is the same, but denies that it is matter. It is instead, he insists, the "qualified body" that results from the blending of the trace-soul with matter',

Enn. III 8 [30] 2, and again On matter, Enn. II 2 [14] 5. For the opposition between

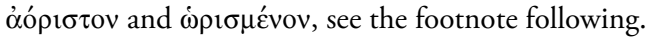

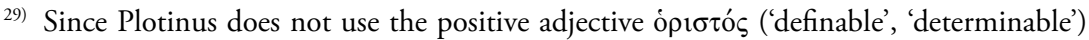

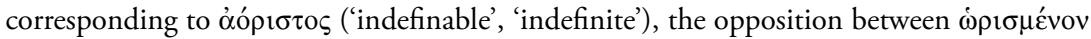
$\tau \imath$ ('something that has been defined' or 'determined', 'something definite'), in his descrip-

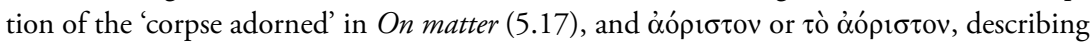
the product of soul in Various investigations (3.12) and in On the daimon (1.14), is as clear as it could be. Here as elsewhere, I deliberately ring the changes in my translations and

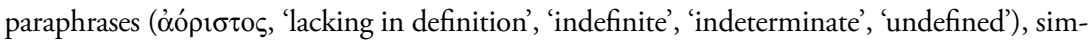
ply to avoid giving the impression that any one translation can be taken as a substitute for the terminology of the original. (In a continuous translation I would aim to do otherwise.) 30) For my correlation of the two treatises, and for the identification of the object described in both treatises as matter, see O'Brien, 1991, 15-25. 
a 'trace-soul' that Phillips claims is none other than the 'corpse-like logos' of On contemplation. ${ }^{31}$

\section{Phillips' 'trace-soul'}

We need only to have read the two earlier texts with minimal care to see at once that the appeal, in this context, to what Phillips calls a 'trace-soul' is quite simply impossible, as impossible for the object spoken of as the 'offspring' of soul, in On the daimon, as it is for the object that is 'made' by a partial soul, in Various investigations. Neither the object that is 'utterly without definition', in On the daimon, nor the object that is 'lacking in definition' and 'utterly dark', in Various investigations, can possibly be identified as an object 'blended' with the 'corpse-like' logos of On contemplation, a logos specifically said to be, or to be the bearer of, 'visible form' ${ }^{32}$

Phillips' reading of the texts would quite simply deprive the two adverbs of their meaning. ${ }^{33}$ The object that is not only 'dark', but 'utterly dark' (Various investigations), not only 'indefinite', but 'utterly indefinite' (On the daimon), is clearly and obviously and surely undeniably a substrate that has no trace of the 'visible form' that would make of it what Phillips calls a 'qualified body', the work of a 'corpse-like' logos in On contemplation.

Phillips' formula, a "'qualified body" that results from the blending of the trace-soul with matter', might possibly apply to the 'corpse adorned' of the treatise On matter, a body that does have some 'adornment', some measure of what we may suppose to be 'visible form', and is therefore specifically said to be 'something definite' (5.17: $\dot{\rho} \rho \sigma \mu \varepsilon ́ v o v \tau \imath){ }^{34}$

But if words have meaning, the object specifically spoken of as 'some-

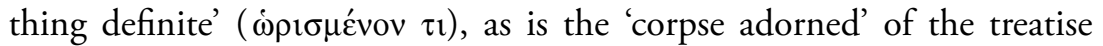
On matter, cannot be the same as the object produced by soul in $O n$ the

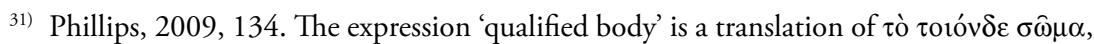
found in Enn. IV 4 [28] 18.9 and 20.24-26 (four occurrences in all). In both places, the expression is associated with a body that experiences pleasures, pains and desires. Hardly suitable, one might therefore have thought, for an object that in our two texts is explicitly said to be lacking in soul and lacking in life. But more on this later ( $\$ 32$ below).

32) See again Phillips, 2009, 134.

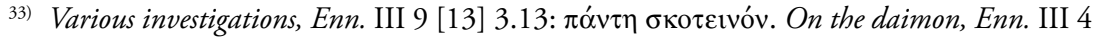

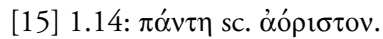

34) For this association of the 'adornment' of the 'corpse adorned' of On matter with the 'visible form' of On contemplation, see above $\$ 13$.
} 


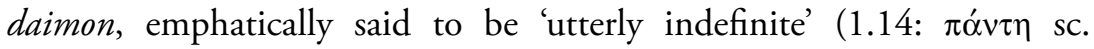

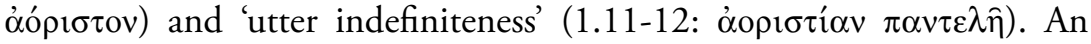
object 'utterly indefinite' cannot possibly have been touched by, much less 'blended' with, a logos that is, or that is the bearer of, the shapes and colours that we may suppose to be associated with 'visible form'. ${ }^{35}$

\section{$A$ logos deprived of light and definition?}

The anomaly is no less if we take things the other way round, so to speak, and therefore start from the role assigned to logos in Phillips' statement of his thesis. This is admittedly easier said than done. In attempting to find a precise meaning for Phillips' allusions to logos in the statement of his thesis, the scrupulous reader (myself) is faced with at least two possibilities.

Does Phillips intend us to envisage the 'corpse-like' logos of On contemplation, one of several manifestations of what he likes to call 'the tracesoul', as working to produce the "qualified body" that results from the blending of the trace-soul with matter', and that is none other, on Phillips' thesis, than the object 'made' by soul in Various investigations and 'given birth to' by soul in On the daimon? Alternatively, is that same 'corpse-like' logos to be seen as itself the object produced by the soul whose activity is recorded in those two treatises?

The latter is certainly the impression given when one works one's way through the serried ranks of references packed tight on the penultimate full page of Phillips' article and discovers the 'corpse-like' logos of On contemplation placed cheek by jowl both with the product of soul said to be 'lifeless' in On the daimon (1.7: $\alpha \zeta \omega v)$ and with the object said to be 'non-

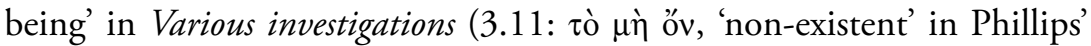
translation). ${ }^{36}$

But perhaps the distinction should not be pressed. Phillips perhaps intends his reader to conclude that, at this level, the formal cause is somehow identified with its product, and that the 'corpse-like' logos of On contemplation therefore both works on, and is, the object produced by soul in On the daimon and in Various investigations.

No matter: the distinction, as the lack of a distinction, requires a reading of the texts that is, again, quite simply impossible. The 'offspring' of

35) For the implications of the expression 'visible form', see above $₫ 9$.

36) Phillips, 2009, 134. 
physis is a logos, a logos that may be a 'corpse', but a logos nonetheless, and a logos associated with, or identical to, 'visible form'. It is merely contradictory to claim that such an entity works to produce, still less that it is constitutive of, what we are told, in no uncertain terms, is an object entirely deprived of light ('utterly dark', Various investigations) and entirely deprived of definition ('utterly indefinite', On the daimon). Light and definition are the very stuff of what it is to be a logos, of what it is to be a 'visible form'.

\section{$\$$ 19. A 'Soul' that Is Not a 'Soul'}

\section{'Indefinite' and 'utterly indefinite'}

As though hoping to find salvation in the principle si peccas, pecca fortiter, Phillips makes his thesis only the more perverse by attempting to argue that the object 'brought to birth' by soul, in On the daimon, and said to be

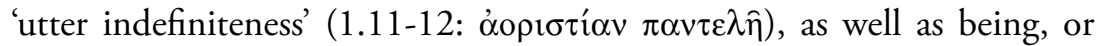
including, both a 'trace-soul' and a logos, is also to be counted as itself 'a manifestation of soul'.

'Nor is it difficult', he writes, 'to understand why Plotinus would classify as "complete indefiniteness" a manifestation of soul.' ${ }^{37}$ The 'difficulty' is supposedly dissipated by Phillips' appealing to a later chapter of Various investigations (cap. 5), where 'soul', a higher soul, is described as 'indefinite'

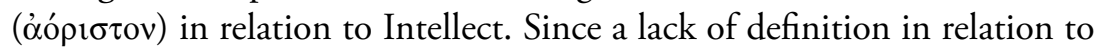
Intellect is possible for a higher soul, therefore-so Phillips would seem to argue - the total lack of definition said to result from soul's 'giving birth' in $O n$ the daimon may likewise qualify as itself 'a manifestation of soul'. ${ }^{38}$

Not only is such an argument vacuous, it is also false. In the context of the expression quoted from On the daimon (1.11-12: $\alpha$ opı $\sigma i \alpha v \pi \alpha v \tau \varepsilon \lambda \hat{\eta}$, 'complete indefiniteness', in Phillips' translation, 'utter indefiniteness', in the translation adopted here), Plotinus draws exactly the distinction that

\footnotetext{
37) See again Phillips, 2009, 134. Phillips' 'complete indefiniteness' is a reference to the 'utter indefiniteness' ( $\alpha$ opı $\tau \tau$ í $\alpha v \pi \alpha v \tau \varepsilon \lambda \hat{\eta}$ ) of the object produced by soul in On the daimon (1.11-12).

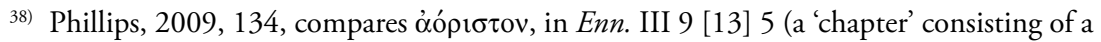
single sentence), used of a higher soul in relation to Intellect, and $\alpha$ opı $\sigma \tau \tau^{\prime} \alpha \nu \pi \alpha v \tau \varepsilon \lambda \hat{\eta}$, in Enn. III 4 [15] 1.11-12, the description of an object 'given birth to' by the soul 'when she comes to be in plants'.
} 
we would have to put to one side if Phillips' argument were to have any show of plausibility.

\section{Phillips' false inference}

In the chapter of $O n$ the daimon describing the object brought to birth by soul when she 'comes to be in plants', Plotinus draws a firm line between what is, and what is not, 'utterly indefinite'. ${ }^{39}$ The 'indefiniteness' attaching

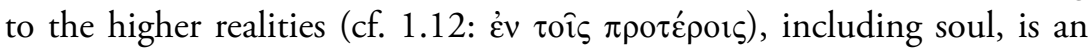
indefiniteness relating to whatever 'form' will be acquired when the object in question turns back towards its source (cf. 1.9-10). Before turning back to its source, the higher reality is specifically stated not to be 'utterly indefinite' (1.13: ov yò $\rho \pi \alpha ́ v \tau \eta ~ \alpha ́ o ́ p i \sigma \tau o v)$, as opposed to the product of the soul that 'comes to be in plants', singled out, by contrast, as what is 'utterly

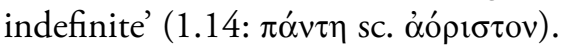

How can Phillips, in quoting the passage, possibly hope to gloss over that very distinction? Is he perhaps not alert to the importance of the

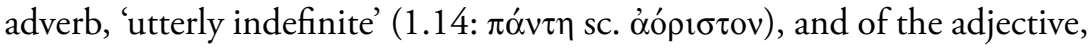

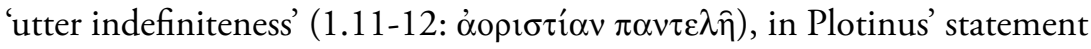
of his thesis? ${ }^{40}$

The description of soul, a higher soul, as 'indefinite' in relation to Intellect does not for one moment allow the inference that an object produced by a lower soul and specifically said to be 'utterly indefinite' may therefore likewise qualify as 'a manifestation of soul'. Plotinus' firm distinction between what is, and what is not, 'utterly indefinite', could almost have been designed to exclude exactly the inference that Phillips seeks to draw when commenting on this very passage.

\section{A soul' that is 'no longer a kind of soul'}

It is true that, when the soul that 'makes' what is 'indefinite' in Various investigations, she does so by herself becoming 'more indefinite' (3.11-12:

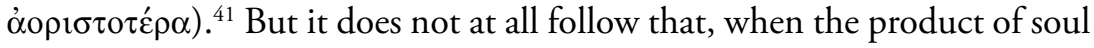

\footnotetext{
39) Enn. III 4 [15] 1. For the 'firm line', see $\$ 16$ above.

40) For Phillips' description of both words (1.12: $\pi \alpha v \tau \varepsilon \lambda \hat{\eta}, 1.13$ and 14: $\pi \alpha$ óv $\eta$ ) as 'adverbs', and for his seeming neglect of the significance attaching to Plotinus' use of either word, see $\$ 28$ below.

41) The passage (Enn. III 9 [13] 3) has been summarised, $\$ 3$ above.
} 
in On the daimon is said to be 'utterly indefinite' and 'utter indefiniteness', it is therefore to be 'classified', not simply as a product of soul, but as 'a manifestation of soul'. 42

Phillips' claim to the contrary again runs clean counter to what is stated specifically in the very text that he himself has quoted. In the very same context in which the product of soul is said to be 'utterly indefinite' (1.14) and 'utter indefiniteness' (1.11-12), it is also said to be 'lifeless' (1.7: پ’ $\zeta \omega v)$

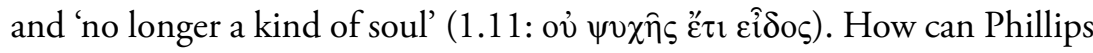
possibly expect his readers to believe that the very thing said not to be a soul, is a soul?

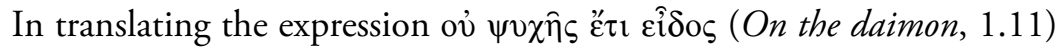
as 'no longer a form of the soul', does Phillips perhaps conceivably hope to suggest that the object in question, 'no longer a form of the soul', might nonetheless somehow be a particular soul? ${ }^{43}$ The suggestion has only to be stated to be seen to be worthless.

Sleeman and Pollet rightly include this use of $\psi v \chi \eta$ under the rubric 'Soul as such, in general'. ${ }^{44}$ The meaning is that the object to which soul gives birth is 'no longer a kind of soul' - or even 'no longer a soul of any kind'. The words that follow, introduced by a repetition of the negative particle and an explanatory $\gamma \alpha \dot{\alpha} \rho$, and even repeating the adverb, make the meaning unmistakably clear. The object in question is 'no longer a kind of

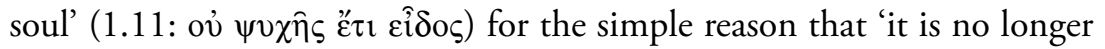

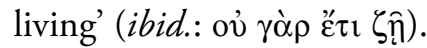

How can the object that is 'no longer living' and 'no longer a kind of soul' nonetheless be, as Phillips claims it is, 'a manifestation of soul', somehow analogous, on a lower level, to the soul that is related to Intellect in the later chapter of Various investigations (cap. 5)?45

\footnotetext{
42) See again Phillips, 2009, 134.

43) For the translation, see Phillips, 2009, 134.

44) Sleeman and Pollet, 1980, s.v. (col. 1127.20). The corresponding use of عîo (s.v., col. 297.43) is listed under the general rubric (d, 1) 'kind, sort, species'.

45) The question whether 'soul' can be 'not a soul' does, as it happens, crop up in Enn. I 8 [51] 11-12, but only as a reductio ad absurdum. If soul were wholly deprived of form, and therefore total privation, it would have to be deprived of life and would then no longer be a soul at all (cf. 11.10-19). From which Plotinus concludes (cap. 12) that soul is not total privation, leaving the field clear for matter, which is total privation, to be primary evil, evil unadulterated.
} 


\section{'Soul' and 'life'}

Plotinus' argument is no different in the preceding lines of the chapter of On the daimon. The soul that comes to be in plants generates something 'totally other than herself' (1.6). This is because 'after it', i.e. after the soul

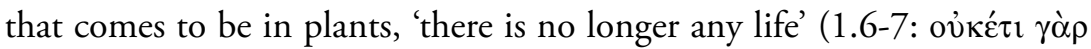

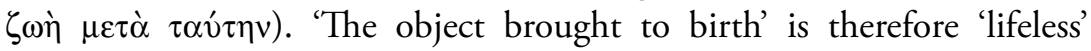

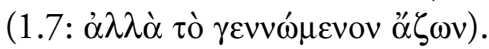

In these sentences (On the daimon, 1.6-7), as later in the same chapter (1.11), 'soul' and 'life' are linked. It is because there is no life below the level of soul, once she 'comes to be in plants' (1.4-5), that the offspring of that same soul is 'lifeless' (1.7) and is therefore 'totally other' than the soul that gave it birth (1.6). So too, only more succinctly, the object that is

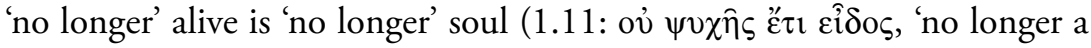
kind of soul', 'no longer a soul of any kind'). To claim of that same object, as Phillips would do, that it is nonetheless 'a manifestation of soul', is to fly in the face of the obvious meaning of the text.

Read again Phillips' wingèd words: 'Nor is it difficult to understand why Plotinus would classify as "complete indefiniteness" a manifestation of soul. ${ }^{46}$ Those desperate words are the words of a drowning man, clutching at straws. 'Nor is it difficult...' No, not difficult, impossible, not least when the object in question is specifically said not to be a soul. ${ }^{47}$

\footnotetext{
46) See again Phillips, 2009, 134.

47) In a much later treatise, the 'last' extension of soul is said to be 'altogether unlimited'

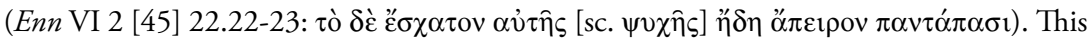

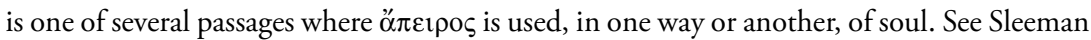
and Pollet, 1980, s.v. ö $\pi \varepsilon$ ipos (col. 118.45-53). Again in a much later treatise (Enn. I 8

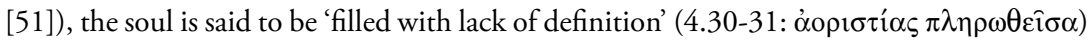
when she 'looks towards' matter, a 'looking' that finds no object for its looking, and a 'seeing' that is therefore no more a 'seeing' than it is when we find ourselves, even with our eyes open, in pitch blackness (cf. 4.31-32). Interesting though these passages may be for a study of the relation of soul to matter, it seems to me pointless, and indeed perverse, to quote either passage, as Phillips has done, 2009, 134 and 134 n. 71, to support his claim that 'utter indefiniteness' is 'a manifestation of soul' when, in the text in question (Enn. III 4 [15] 1), Plotinus goes out of his way to tell us, in no uncertain terms, that the 'utter indefiniteness' in question, the 'utter indefiniteness' produced by soul, is not itself a soul.
} 


\section{Lucida tela diei}

A 'manifestation of soul' that is specifically said not to be a soul. ${ }^{48} \mathrm{~A}$ logos that is specifically said to be 'without $\log s^{\prime}{ }^{4}{ }^{49} \mathrm{~A}$ 'visible form' that is 'utterly dark'. ${ }^{50}$ Such is the topsy-turvy world that Phillips has created for the hapless student who tries to keep him company on his journey through the Enneads.

Return to sanity and the light of day. The obvious comparandum, alike for the object 'utterly dark' (Various investigations) and for the object 'utterly indefinite' (On the daimon), will be the substrate before it has received the 'visible form' given to it by physis, 'the maker of form' (On contemplation). It will therefore be the 'darkness of matter' that has not yet been modified as 'earth' or 'water' (The three principal hypostases). It will be the substrate that is matter before it has become 'something definite' and a 'corpse adorned' (On matter).$^{51}$

If that is so, then the origin of matter is not in doubt. The object that is 'utterly dark', and that is therefore, in all probability, nothing other than matter, has been 'made' by 'a partial soul' (Various investigations). The object that is 'utterly indefinite', and that is again therefore, in all probability, nothing other than matter, has been 'brought to birth' by soul when she 'comes to be in plants' (On the daimon). The knell rings loud and long for the final demise of Phillips' argument. ${ }^{52}$

\footnotetext{
48) A 'manifestation of soul' is Phillips' comment, 2009, 134, on the object specifically said not to be a soul in the opening chapter of On the daimon, Enn. III 4 [15] 1.

49) The logos of On contemplation, Enn. III 8 [30] 2.29-31, is identified by Phillips, 2009, 134, with the object said to be alogos in Various investigations, Enn. III 9 [13] 3.13, and with the object said to be 'utterly without definition' in On the daimon, Enn. III 4 [15] 1.13-14.

50) The object associated with, or identified with, 'visible form' in On contemplation (2.3031), is identified by Phillips, 2009, 134, with the object said to be 'utterly dark' in Various investigations (3.13).

51) The object produced by soul in Various investigations, Enn. III 9 [13] 3, and On the daimon, Enn. III 4 [15] 1, is supplied with a comparandum drawn from the three passages where there is mention of a 'corpse', The three principal hypostases, Enn. V 1 [10] 2, On matter, Enn. II 4 [12] 5, and On contemplation, Enn. III 8 [30] 2.

52) I express myself in this forceful fashion partly for the sake of clarity. There is, of course, no 'explicit' mention of matter in the text of Various investigations or in the chapter from On the daimon, nor have I ever said that there was, despite Phillips' bold, but false, claim to the contrary (see $\$ 4$ above). The whole point of the exercise is to determine whether,
} 


\section{$\$$ 20. Matter and Body}

\section{From lack of form to form}

With that simple conclusion in mind, we may return, with some hope of enlightenment, to the detail of the treatise $O n$ the daimon. The concluding lines of the opening chapter are designed to complete the contrast with entities produced earlier in Plotinus' scheme of emanation..$^{53}$ The object that soul has brought to birth 'when she comes to be in plants' is not left as a total lack of definition, any more than the object born before it, initially 'bereft of form' (1.8: $\dot{\alpha} \mu$ óp $\varphi \omega \tau$ ) $)$, is left in that state. But the means by which either object acquires form and definition are not the same.

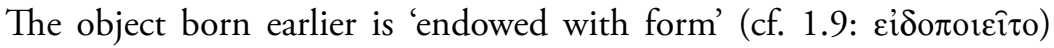

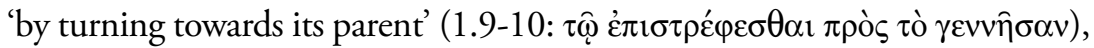
'as though receiving nourishment' from the principle that gave it birth

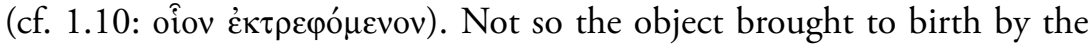
soul that 'comes to be in plants'. Although this too 'takes on the form that

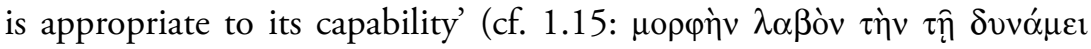
$\pi \rho \sigma^{\circ} \varphi$ ороv), and therefore 'becomes body' by 'being completed' (1.14-15:

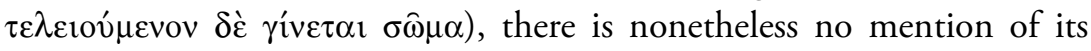
'turning towards its parent' prior to the process of its receiving form. We are told simply that, following its reception of form, soul's offspring provides a 'receptacle' for the principle that both 'gave it birth and gave it nourishment' (cf. 1.15-16: نં

The difference between the two descriptions is no doubt deliberate. The object that soul has given birth to, repeatedly said to be 'lifeless' (1.7), 'no longer a kind of soul' and therefore 'no longer alive' (cf. 1.11), is unable to do as the objects produced earlier in the scheme of emanation have done, and is unable therefore to turn of itself towards its parent. For the object

despite the absence of any explicit reference to matter, it is nonetheless matter that is referred to when Plotinus describes, in detail, the object 'made' by soul in Various investigations and the object 'brought to birth' by soul in On the daimon. Despite my never having referred to an 'explicit' mention of matter in either text, Phillips is right in divining my conclusion to be that what is not said explicitly is nonetheless very clearly implied. The implication does nonetheless remain an implication, very possibly for the reason indicated below ( $\$ 36$ — —and despite Phillips' vain attempts (see again $\$ 4$ above) to have me say otherwise.

53) I return to Enn. III 4 [15] 1 . See $\$ 16$ above. 
produced by soul to 'take on form' and 'become body', there have to be two separate and (logically) successive acts on the part of the soul from which it derives, a soul which therefore acts as both 'parent' (1.16:

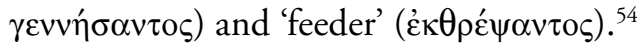

\section{The two activities of soul}

So it is also mutatis mutandis in Various investigations. Once we have recognised that the object 'utterly indefinite' of On the daimon is none other than the object 'utterly dark' of Various investigations (see $\$ 17$ above), we appreciate that the difference between the two activities of 'giving birth' and 'giving nourishment', in $O n$ the daimon, marked by the conjunction

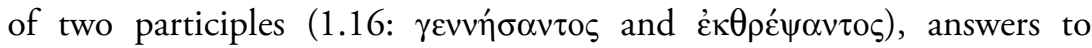
the difference between the soul's first and second 'initiative', in Various investigations. ${ }^{55}$

In On the daimon, the principle that 'gives birth' to an object 'utterly indefinite' has to take it upon itself to 'nourish' the object that it has produced. Those two actions correspond to the soul's two 'initiatives', in first 'making' an object that is 'utterly dark', and then 'covering' the object that she has made 'with form', in Various investigations. Soul's 'nourishing' the object that, when she first 'gave birth' to it, was 'utterly indefinite' (On the

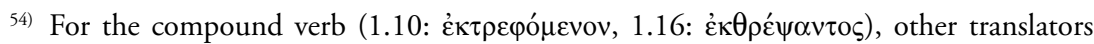
prefer 'rear' or even (with emphasis on the prefix to the verb, غ̇к-) 'rear to maturity' (so Armstrong, 1967, ad loc. [p. 143]). I prefer a more down-to-earth translation, as more in keeping with Plotinus' liking for 'bildhafter sinnlich-konkreter Ausdrücke' (Schwyzer, 1951, 526.28-30). 'Nourishing' or 'feeding' is well within the range of meanings accruing

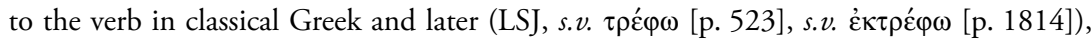
even if the original use of the verb is not restricted to 'giving food' (cf. Chantraine, 1968, s.v. $\tau \rho \varepsilon ́ \varphi \omega$ [p. 1133-1135]). We may well wonder how soul is able to 'feed' or 'rear' an object that is 'lifeless' (1.7: $\alpha \zeta \omega v)$. But such questions arise only if we treat what are images and metaphors as approximating to full-blown allegories, which they are not. On the only other occasion when Plotinus uses the compound verb, in The three principal hypostases (Enn. V 1 [10]), it is to speak of Intellect as both 'giving birth to' and 'nourishing' soul (3.12-15), the same conjunction of the two verbs that we have in On the daimon

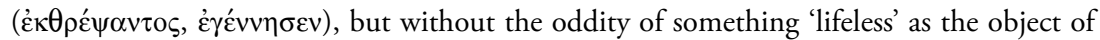
the verb.

55) The comparison here lies between Enn. III 4 [15], On the daimon (1.16: 'giving birth' and 'giving nourishment'), and Enn. III 9 [13], Various investigations (3.15: the soul's 'second initiative'). For the implied first 'initiative', see $\$ 3$ above. 
daimon), is none other than soul's 'covering with form' the object that, when it was first 'made', was 'utterly dark' (Various investigations).

\section{The form of 'body'}

The parallel with $O n$ the daimon gives us therefore a more detailed understanding of the soul's two 'initiatives' in Various investigations. When Plotinus tells us, in On the daimon, that what starts off as 'utterly indefinite' (1.14) 'takes on the form appropriate to its capability' (1.15) and therefore, 'by being completed becomes body' (1.14-15), as a result, so it is implied, of the principle that 'gave it birth' having also 'given it nourishment' (cf. 1.16), we are being told, only in more detail, what happens when the soul, having 'made' an object that was 'utterly dark', 'covered' that same object 'with form', in Various investigations (3.15-16). In Various investigations as

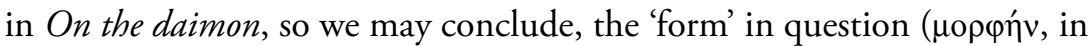
On the daimon, દ̇uó $\rho \omega \sigma \varepsilon$ in Various investigations) is, or includes, the form of body or 'bodilyness..$^{56}$

The object that is 'utterly indefinite' (On the daimon) and 'utterly dark' (Various investigations) becomes 'body' by its reception of the form of body or 'bodilyness' as the result of a second and (logically) subsequent action on the part of the principle that, prior even to its transmission of form, 'gave it birth' (in the language of $O n$ the daimon) or 'made' it (in the language of Various investigations).

\section{A bodiless matter}

But what was the object 'utterly indefinite' and 'utterly dark' before it took on the form of body? What was it in its bodiless state? To suppose, as Phillips' thesis would require us to do, that, even before it has received the form of body, what is 'utterly dark' and 'utterly indefinite' is comparable to, or even identical with, a logos related to 'visible form', is so incongruous that even to state the supposition is to reject it. ${ }^{57}$

Can we conceive of a logos associated with 'visible form', and therefore with shape and colour, as being itself 'utterly indefinite' and 'utterly dark'?

56) The existence of such a form is frequently attested. See Sleeman and Pollet, 1980, s.v. $\sigma \omega \mu \alpha \tau$ tó $\eta$ (col. 1002.40-48). The need for such a form is made much of in the second half of On matter (cap. 6-16).

57) See again Phillips, 2009, 134. 
Conversely, can we imagine something that as yet has no body nonetheless somehow endowed with shape and colour? A ghost perhaps? A mirage? The imagination boggles.

Once we abandon the comparison of what is 'utterly dark' and 'utterly indefinite' (the product of soul in Various investigations and in On the daimon) with 'visible form' (the product of physis in On contemplation), the question becomes simple, and the answer becomes obvious. What is it that is 'utterly dark' (Various investigations) and 'utterly indefinite' (On the daimon), that has not yet received the form of body and that has therefore not yet received the shapes and colours associated with 'visible form'? Candidates other than matter, please step forward. Are there any?

\section{$\$ 21$. 'Demiurgic' Powers in Proclus}

\section{Proclus' two 'makings'}

We have only to recognise that simple parallel, between the double activity of soul in On the daimon ('giving birth' and 'giving nourishment') and the double activity of soul in Various investigations ('making' and 'covering with form'), to see, once again, how misguided is Phillips' attempt to call upon Proclus as support for his interpretation of the Enneads.

Phillips claims that the two 'initiatives' of a 'partial soul' in Various investigations are 'in all salient points identical' to a distinction that Proclus draws, in his commentary on the Timaeus, between two 'demiurgic' mak-

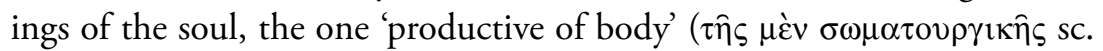

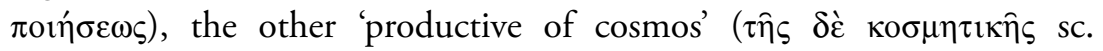
$\pi$ oiń $\sigma \varepsilon \omega \varsigma) .{ }^{58}$ Here, as earlier in his article, Phillips has wholly misconstrued the terms of a possible comparison. ${ }^{59}$

\section{The 'making' of body}

When the object brought to birth by soul in On the daimon 'takes on the form appropriate to its capability', it does so by 'becoming body'

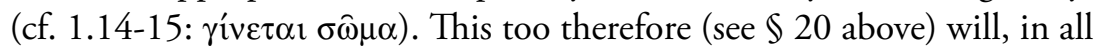

58) Proclus, in Tim. i 383.1-22. Phillips, 2009, 132-133.

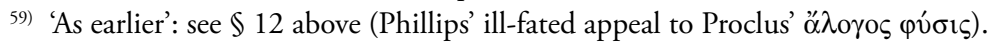


likelihood, be the implication when the soul, in Various investigations, 'covered' the object she had made 'with form'. The 'form' that the soul has conferred, by her 'second initiative', will be, or will include, the form of bodilyness. The soul's first initiative lies in 'making' an object that is 'utterly dark' and therefore totally without form. The addition of 'form' to what has been 'made', and therefore the production of body, is a result of the soul's second initiative.

If therefore, as Phillips wishes, we are to establish a comparison between the soul's two 'demiurgic' makings, in Proclus' commentary on the Timaeus, and the soul's two 'initiatives', in Various investigations, then the comparison, if it is to be a comparison of like with like, will have to be a comparison of the two activities that issue in the production of body. The soul's first 'making', her 'somaturgic' making, in the pages of Proclus, will have to be compared with the soul's second 'initiative' in the Enneads, her 'covering' the object she has made with 'form', a form that is, or that will include, the form of body.

\section{Phillips' false comparison}

Here as earlier, Phillips' attempted comparison has therefore totally misfired. The comparison, if comparison there has to be, between Proclus' two 'makings' and the two 'initiatives' of soul in Various investigations, will not lie, as Phillips supposes, between Proclus' first 'making' and the soul's first 'initiative'. Proclus' first making, a 'somaturgic' or 'bodily' making, has to be compared to the soul's second initiative, when she covers the object she has made with form, a form which we may infer from On the daimon will be, or will include, the form of body.

The difference, if we are looking to determine the nature of the object 'utterly dark' that the soul has 'made' as a result of her first initiative, is crucial. The soul's action in producing 'body', by her imposition of 'form', necessarily presupposes the prior existence (even if only a logical priority) of the object that will receive the form. The production of body is therefore necessarily subsequent to what is 'brought to birth' by soul, in $O n$ the daimon, and subsequent therefore to what is 'made' by soul, as the result of her first initiative, in Various investigations.

Proclus' distinction between a making 'productive of body' and a making 'productive of cosmos' is therefore not at all the same as Plotinus' distinction between a first and a second initiative of soul in Various investigations. 
The soul that produces body in Plotinus does so as the result of a second initiative. Her first initiative does not correspond to either of Proclus' two 'demiurgic' makings. Phillips' proud claim that the two initiatives of a 'partial soul' in Plotinus are 'in all salient points identical' to Proclus' two 'demiurgic' makings is quite simply and quite obviously mistaken.

\section{$\$$ 22. Soul and Cosmos}

\section{An emended comparison}

If we are to find a place for soul's first initiative in the passage that Phillips has quoted from Proclus' commentary on Plato's Timaeus, we shall find it, not in either of the two 'demiurgic' makings that Phillips has referred to, but in the continuation of Proclus' commentary, when he specifically poses, only to set aside, the question of the origin of matter. ${ }^{60}$ Proclus is well aware that the 'making' of 'body' has to have for its object a preexisting substrate. But the nature and the origin of that substrate is deliberately set to one side in the passage that Phillips has quoted.

The distinction between two 'demiurgic' makings, one a making of 'body', the other a making of 'cosmos', as Proclus himself very clearly lets it be seen, in the continuation of his commentary, is subsequent to, and dependent upon, the question of the origin of matter. So too in the Enneads. The production of 'body' is dependent upon, and is (logically) subsequent to, the soul's action in 'giving birth to' and 'making' the object that is 'utterly indefinite' and 'utterly dark', prior to its reception of the form of 'bodilyness'.

\section{Phillips' appeal to Proclus}

Here as earlier, Phillips' appeal to Proclus serves therefore only to demonstrate his misunderstanding of the text of the Enneads, his failure to realise that, in On the daimon as in Various investigations, the production of 'body' is subsequent to the 'bringing to birth' of an object that is 'utterly indefinite' (On the daimon), and subsequent therefore to the 'making' of an object 'utterly dark' (Various investigations).

60) Proclus, in Tim. i 384.1 sqq. 
The object that is 'utterly indefinite' (On the daimon) and 'utterly dark' (Various investigations) is an object whose existence is prior, if only logically prior, both to the 'nourishment' that is given by the soul (On the daimon), and to the soul's 'second initiative' (Various investigations). The 'making' of 'body' in Proclus' commentary on the Timaeus may perhaps be compared to the origin of 'body' in On the daimon, and by implication in Various investigations. But it does not for one moment follow that Proclus' two 'demiurgic' makings are, as Phillips so boldly claims, 'in all salient points identical' to the soul's two 'initiatives' in the Enneads. ${ }^{61}$

The comparison of Proclus' 'somaturgic making' with the soul's 'second initiative' has no direct bearing on the identity of the object that the soul has made as the result of her first initiative, the object that is 'utterly indefinite' before 'receiving' the form of body in On the daimon, 'utterly dark' before being 'covered by form', presumably including the form of body, in Various investigations.

\section{Phillips' avoidance of the obvious}

No direct bearing-but is there not, all too obviously, an indirect consequence to be drawn from the comparison? The conclusion one might well think to be implied by the comparison of Proclus' first making, a 'somaturgic making', with the soul's second initiative is the very conclusion that Phillips, throughout his article, is at such pains to avoid.

Once we have correctly aligned the terms in the comparison that Phillips has himself proposed, between the first of the soul's two 'demiurgic' makings in Proclus' commentary on the Timaeus and the second 'initiative' of soul in the Enneads, the all-too-obvious question calls for an all-tooobvious answer. If Proclus' first making, a 'somaturgic' making, corresponds to the soul's second initiative in Various investigations, then what can be there be, in the text of Proclus, corresponding to the soul's implied first initiative?

When Proclus, in describing the formation of 'body' and in describing the formation of 'cosmos', so clearly and so deliberately sets to one side the question of the origin of matter, ${ }^{62}$ what possible parallel could there be, in

61) See again Phillips, 2009, 132-133.

62) See again Proclus, in Tim. i 384.1 sqq. 
the text of the Enneads, to this prior event, if not the soul's 'giving birth to' and 'making' the object that acts as a substrate for the form of body and that is therefore none other than matter?

Once again (see $₫ 13$ above), the very text that Phillips seeks to quote against me, if rightly understood, tells in my favour. Proclus' question on the origin of matter finds an obvious answer in the soul's making of matter in the Enneads.

\section{A prior 'making' of matter}

The sadness - for it is a sadness - is that Phillips had only to pay closer attention to the parallel I had already drawn, between the soul of Various investigations and the soul of $O n$ the daimon, to arrive at both a clearer understanding of the passage he has quoted from Proclus and a more balanced appreciation of possible comparisons with the text of the Enneads. ${ }^{63}$

When the soul of On the daimon has both 'given birth' to what is 'utterly indefinite', and has then 'given nourishment' to her progeny, which is thereby 'completed', in so far as, by 'receiving form', it 'becomes body' (1.14-16), the resulting conjunction, the object that soul has both 'given birth to' and 'fed', is said to act as a 'receptacle' to the principle responsible

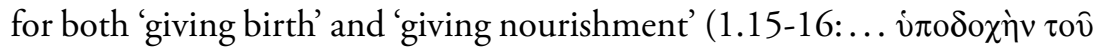

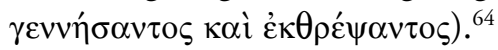

Is that any different from the soul of Various investigations, which having 'made' darkness, and having 'covered' the darkness 'with form', 'enters rejoicing' into the object that, thanks to its covering of form, has been made suitable for her 'entry'?

In Various investigations as in On the daimon, the soul's successive actions, in first 'making' or 'generating' and then 'nourishing' or 'covering with form' the object that has been 'made' or 'brought to birth', are said to culminate in soul's taking possession of her product, once the product has been covered with form. The soul 'enters rejoicing' into what the later

63) For the parallel between Various investigations and On the daimon, see again O'Brien, 1991, 15-25 (cf. $\$ \$ 16$ and 17 above).

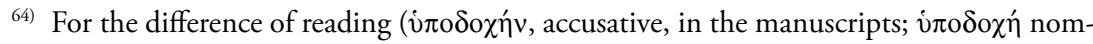
inative, Kirkhhoff's emendation), see the section following ( $\$ 23)$. 
treatise specifies as 'body', the 'body' that includes 'plants', and that, in both treatises, we may assume to be none other than the visible cosmos. ${ }^{65}$

\section{The 'receptacle'}

If that is so, we find, in Plotinus' description of the 'receptacle', in On the daimon, as in his account of the soul's 'joyful entry' into the object she has made, in Various investigations, a near enough counterpart to the 'cosmosmaking' power of Proclus' commentary on the Timaeus. ${ }^{66}$

Proclus' two 'demiurgic' makings are, first, a 'making of body' and secondly a 'making of cosmos'. In those two 'makings', we have therefore an equivalent, if only a loose equivalent, to the soul's 'second initiative' and her subsequent entry 'rejoicing', into the 'image' she has made, once it has been 'covered' with 'form' (Various investigations), and an equivalent, if again only a loose equivalent, to soul's 'nourishment' of her offspring and her subsequent occupation of the 'receptacle', the 'body' that thanks to the presence of form has been made ready to receive her (On the daimon).

\section{The prior existence of matter}

Proclus' two 'makings' do therefore find a rough and ready parallel in the text of the Enneads, but not in the way that Phillips supposes. Proclus' 'somatic' and 'cosmic' makings correspond to the soul's 'second initiative' and her 'joyful entry' (Various investigations), to her 'feeding' her offspring with the nourishment of form and her occupation of the 'receptacle' that is thereby provided for her (On the daimon).

The soul's 'making' of what is 'utterly dark' and 'non-being' (Various investigations) as also the soul's 'giving birth' to what is 'utterly indefinite' (On the daimon) are (logically) prior events, alluded to by Proclus only in so far as, in the pages where he expatiates on the two 'demiurgic' makings, he sets aside the question of the origin of matter, the matter whose (logically) prior existence is indispensable alike for the making of 'body' and for the making of 'cosmos'.

65) For the same scenario, but without the parallel from $O n$ the daimon, see $₫ 14$ above.

60) See again Proclus, in Tim. i 383.1-22 ( 


\section{$\$ 23$. Two 'Last' Things}

\section{'The last of things above', 'the last of what is below'}

With that simple scheme in mind, read the no less simple conclusion that it leads to, with what is, for Plotinus, almost an attempt at style, as expressed in the concluding words of the opening chapter of $O n$ the

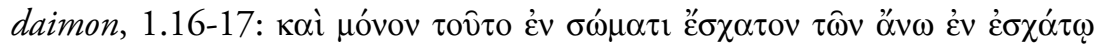

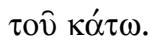

The antecedent to the demonstrative pronoun ( $\tau 0 \hat{\tau} \tau 0)$ is provided by

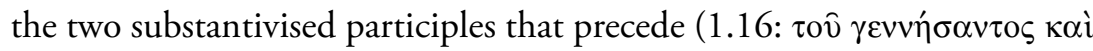

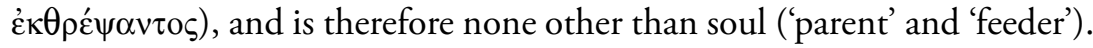

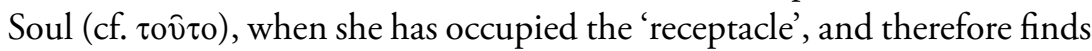
herself 'in body' ('่v $\sigma \omega \dot{\mu} \mu \alpha \tau)$ ), is 'the last of things that are above' ("

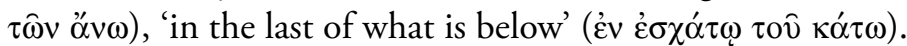

The meaning of that rhetorical flourish, the repetition of $\ddot{\varepsilon} \sigma \chi \alpha \tau o \varsigma$, first as a nominative, secondly as a dative, coupled with the opposition between 'above' and 'below', is plain enough. The soul that has entered the 'receptacle', and therefore now occupies the body of the visible world, is indeed the 'last' representative of the immaterial realities issuing, directly or indirectly, from the One, and is therefore 'the last of things that are above'

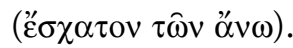

When she is 'in body' ('่v $\sigma \omega ́ \mu \alpha \tau \imath)$, she is to be found 'in the last of what

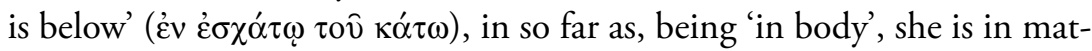
ter. Matter, albeit matter that has 'become body' by its 'reception' of form, and that is able therefore to act as a 'receptacle' for soul (cf. 1.14-16), is nonetheless the last and the least of the objects flowing, however indirectly, from the One, the last and the least of the objects required for the existence of the world 'below', the world that we see and feel around us.

\section{A straightforward reading of the Greek}

So much is, clearly enough, what is implied by a straightforward reading of the Greek. In the preceding sentence, the penultimate sentence of the opening chapter of $O n$ the daimon (1.14-16), Plotinus writes as follows of

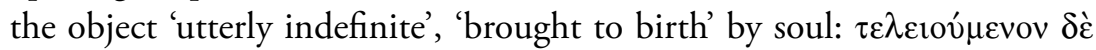

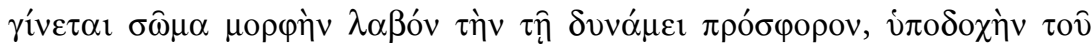

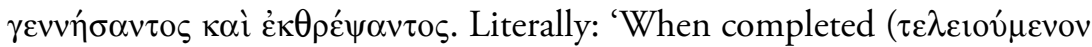




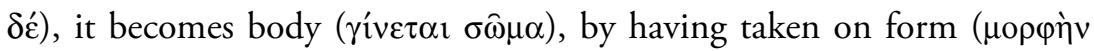

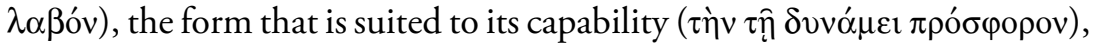
a receptacle ( $\dot{\pi} \pi \delta \delta \chi \eta$ 'v) of (or 'for') the principle that gave it birth and that

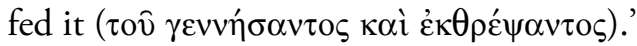

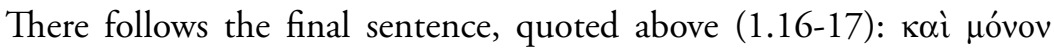

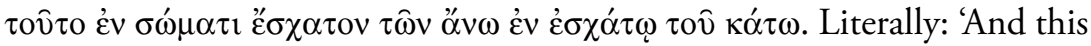

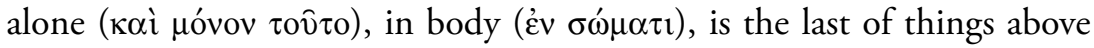

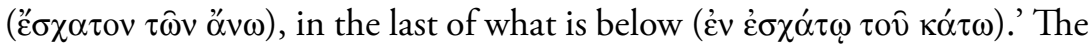
translation of the final sentence requires the addition of a verb, and I have therefore slipped in a simple 'is'. It would be artificial to suppose that, in

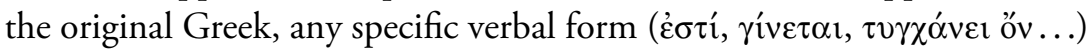
is to be supplied from the inner ear at any specific point in the sentence. ${ }^{67}$

\section{A 'body' that is 'in body'?}

Phillips has a wholly different, and to my mind wholly erroneous, interpretation of the text. ${ }^{68} \mathrm{He}$ takes the object referred to by the adjective है $\sigma \chi \alpha \tau o v$ (nominative) in the sentence quoted above (On the daimon, 1.1617), and therefore the antecedent of the demonstrative pronoun ( $\tau 00 \overline{\tau o}$ ), to be, not soul, but the object that has been brought to birth by soul. The object described as 'utter indefiniteness', once it has been 'completed' by 'taking on form' (1.14-16), Phillips supposes to be the same as the object that in the final sentence of the chapter (1.16-17) is said to be 'the last manifestation in body of the principles above it in the last level of the world below'. ${ }^{69}$

67) In the penultimate sentence, $\dot{\pi} \pi \circ \delta \mathrm{\alpha} \chi \eta^{\prime}$ (accusative) is the unanimous reading of the manuscripts. I shall consider, in the course of this section, the claims of $\dot{\pi} \pi \circ \delta \circ \chi \eta$ (nominative), Kirkhhoff's emendation. Throughout this section, I refer, largely for convenience, to a penultimate (1.14-16) and to a final sentence (1.16-17), relying on the colon or semicolon that separates the two groups of words in Henry and Schwyzer's edition. The two groups of words are syntactically independent (despite the absence of any specific verbal form in the final sentence). If a colon or a semi-colon matches our modern convention better than a full-stop would do, it is simply because it avoids beginning a new sentence with 'And' (1.16: $\kappa \alpha i$ ). How, if at all, Plotinus himself would have marked the transition is anybody's guess.

68) Phillips, 2009, 107 and 134.

69) Phillips, 2009, 107. 
But how can that be so? The object that, when it first appears, is 'utterly indefinite', 'becomes body' by acquiring form (1.14-16). How can what

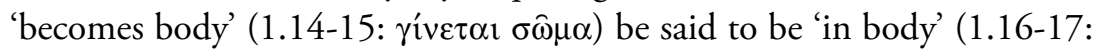
$\dot{\varepsilon} v \sigma \omega ́ \mu \alpha \tau)$ ? How can something be 'in' itself? Such a conception is perhaps not intrinsically impossible. It is indeed a source of one of the many antinomies that Plato makes play with in the Parmenides. But there is not the slightest sign that Plotinus has any so exotic and potentially anomalous a conception in mind when he speaks of the two 'last' things ('̌́ $\sigma \alpha \tau$ ov, $\dot{\varepsilon} v$ $\dot{\varepsilon} \sigma \chi \alpha \dot{\alpha}(\omega)$ in the concluding words of the opening chapter of On the daimon.

\section{Is 'form' one of the two 'last things'?}

To avoid that anomaly (a 'body' that is 'in body', a thing that is 'in' itself), we may think to look back to the sentence preceding (1.14-16) and to pluck out 'form' as the antecedent of the demonstrative pronoun, and therefore as the first "̌ $\sigma \chi \alpha$ tov. When what is utterly indefinite 'takes on

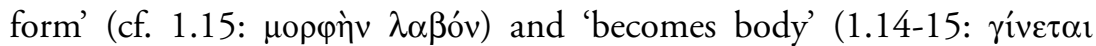
$\sigma \omega \hat{\omega} \alpha)$, the 'form' in question would then be 'the last of things that are above', and therefore 'in body'.

This is none other than the interpretation adopted by Sleeman and Pollet. ${ }^{70}$ It may seem, at first sight, an appealing interpretation: the form

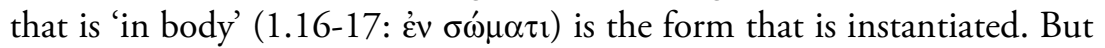
the appeal wears thin once we try to think through the implications.

Since the object that has been brought to birth 'becomes body' (1.14-

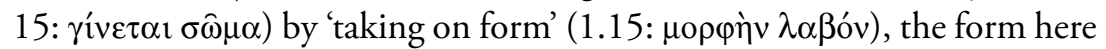
spoken of is, or presumably includes, the form of body. Such a form might well have seemed something of an oddity to the author of the Phaedo, or even of the Timaeus. But, granted that a form of body-'bodiness' or 'bodilyness'-is undoubtedly a feature of the philosophy of the Enneads, why should such a form be singled out (1.16-17) as 'the last', or even 'the

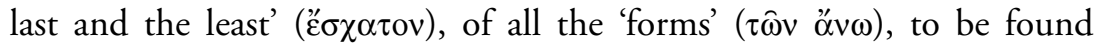

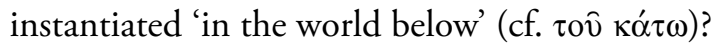

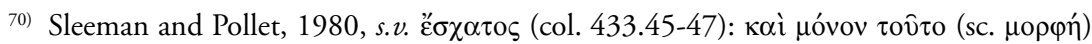

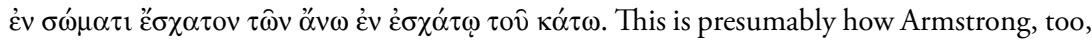

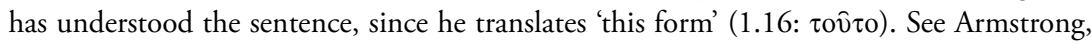
1967, ad loc. (p. 145).
} 
More perplexing still: how can the form of body be said to be itself 'in body' (1.16-17: غ̇v $\sigma \omega ́ \mu \alpha \tau)$ ? Would there even be a 'body' for the form to be 'in', were it not for the presence of the form that is 'in' it? Can any form be said to be 'in' that same form as instantiated? Can any form, even instantiated, be said to be 'in itself'?

\section{Kirkhhoff's emendation}

Does it perhaps help to alleviate that difficulty if, in the penultimate sentence of the chapter (1.14-16), we adopt the reading recorded by Sleeman and Pollet in their Lexicon, an emendation of the text proposed

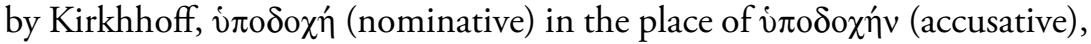
the unanimous reading of the manuscripts? ${ }^{71}$

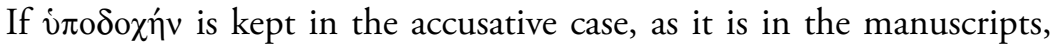
then it has to be understood as looking back directly to the accusative

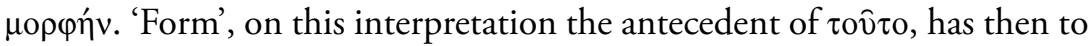

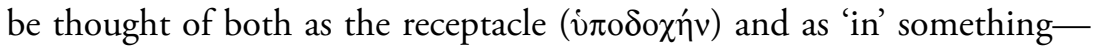
('body', $\sigma \omega \dot{\mu} \alpha \tau \imath$ )— that we might have thought was itself a 'receptacle'. Can a body that is a receptacle have 'in' it something that is also a receptacle? Possibly. But not at all easily or obviously so.

If the word is put in the nominative, as Kirkhhoff proposes ( $\left.\dot{v} \pi \mathrm{o} \delta \chi_{\chi \eta}\right)$, it may be heard instead as looking back to $\sigma \hat{\omega} \mu \alpha$, the nominative preceding. The 'receptacle' ( perhaps a trifle less odd to suppose that the object that will be said to be in body' and therefore 'in' the receptacle, is none other than the form ( $\mu о р \varphi \eta$ v, as the antecedent of $\tau$ ov $\tau$ o).

But we are now back in the difficulty already noted. The 'form' in question is, or includes, the form of body. Can the 'form' of body be said to be 'in' a body? Can a form be 'in' that same form as instantiated?

\section{The antecedent of the demonstrative pronoun}

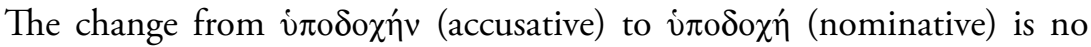
more than a palliative. Neither inflection of the word (1.15) can release us

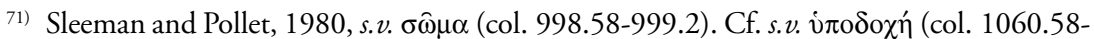
59). Kirkhhoff's emendation (1856) is printed by Schwyzer in the editio minor of Henry and Schwyzer (1964). Henry, in the editio maior (1951), keeps to the unanimous reading

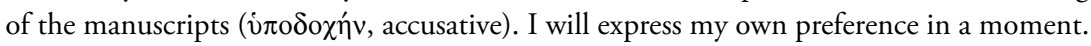


from the underlying anomaly of an object—whether form or the body that has been constituted by form-being said to be 'in' itself. To avoid that almost impossibly awkward anomaly, we need only return to the most elementary facts of logic and of syntax. First the syntax.

What is the antecedent of the demonstrative pronoun in the final sentence of the chapter (1.16: $\tau 0 \hat{\tau} \tau 0)$ ? From the point of view of sheer proximity, there are two possible candidates, in so far as the demonstrative pronoun (1.16: $\tau 0 \hat{v} \tau$ ) may be heard as looking back to either one of the components that make up the concluding expression of the sentence preceding

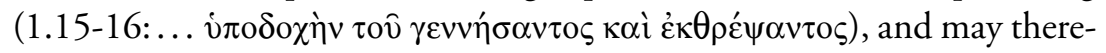

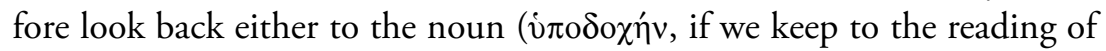
the manuscripts) or to the pair of substantivised participles that depend upon the noun (

If the demonstrative pronoun ( $\tau 0 \hat{\tau} \tau \mathrm{o}$ ) looks back to 'form' or to 'body', or to some combination of the two, then the immediate antecedent, in the

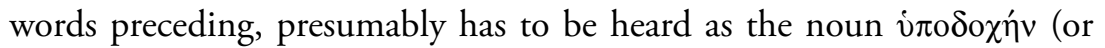

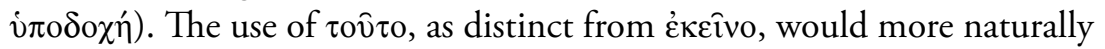
lead the reader to choose the nearer of the two expressions, and therefore 'the parent and feeder', as the successful candidate. ${ }^{72}$

What helps to clinch that same choice is the difference of gender. The

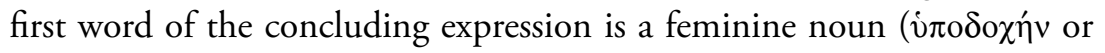
vं the point of view merely of morphology, could be either masculine or neuter. But since there is no masculine noun in the offing, and since we have already had tò $\gamma \varepsilon v v \eta \hat{\sigma} \sigma v$, the same expression in the neuter only a few lines earlier (1.9-10), it would be artificial to take the two participles as any-

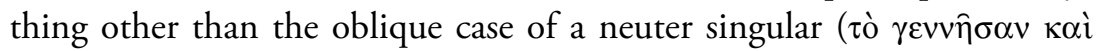
$\dot{\varepsilon} \kappa \theta \rho \varepsilon ́ \psi \alpha v)$.

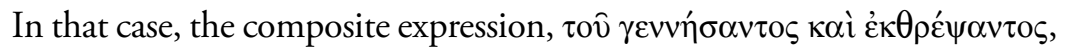
'the principle that gave birth to and that fed', is far and away the more likely antecedent of a demonstrative pronoun that is also a neuter ( $\tau \circ \hat{\tau} \tau$ ).

\section{A conflict of gender}

It is true that Plotinus is not always as scrupulous as he might be in matching words and expressions of the same gender. The distinction between

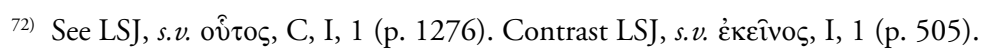


masculine and neuter is even perhaps a trifle arbitrary in the case of an author who can write, as Plotinus does at one point, ö $\tau \alpha v \hat{\omega} \sigma 1$ póvor

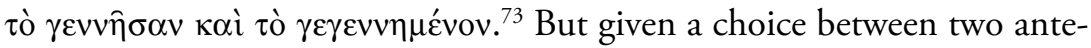
cedents, one feminine (

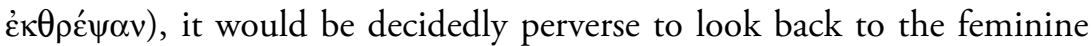
noun as the antecedent for a neuter demonstrative.

Laxity in the present context is to be found, if at all, only in the point that the ultimate antecedent, the reality referred to by the expression

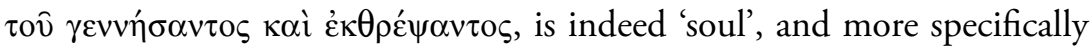
the soul that 'comes to be in plants' (1.4-5). But 'soul' designated by a

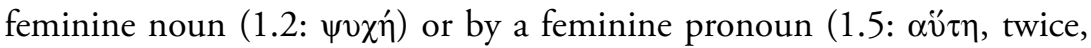
1.6: $\alpha \dot{\tau} \tau \hat{\varsigma}, 1.7: \tau \alpha v i \tau \eta v)$ has long faded from the inner ear. Ten lines of text have intervened, and it is entirely natural for the soul's twin functions of 'giving birth to' and 'feeding' to be summarised by a pair of substantival

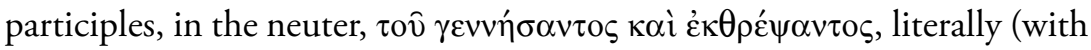
a noun, as nondescript as possible, slipped in to mark the use of the article) 'the principle that gave birth to and that fed', or a trifle more freely, the parent and feeder. ${ }^{74}$

\section{Case and preposition}

That same conclusion is amply confirmed if we turn to the logic of the passage, marked by the transition from a noun in the genitive case, at the

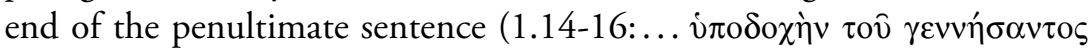

\footnotetext{
73) Enn. V 1 [10] 6.51. Cf. Schwyzer, 1951, 315.7-9.

74) In On immortality, discussing what is in fact the soul (Enn. IV 7 [2] 13.1: Plotinus first writes, abstractly as it were, in the neuter (13.4-8), of a principle 'yearning'

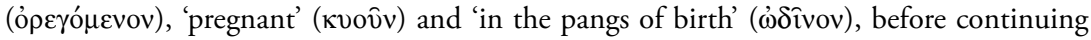
with a string of participles, still in the nominative, but now all in the feminine (13.9-13).

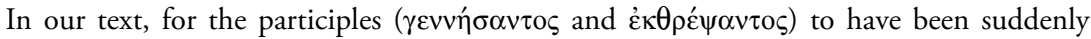
put in the feminine, with a change of case and without explicit repetition of $\psi v \chi \eta$, would have been highly artificial, and would have made it difficult to continue with a simple demonstrative pronoun (presumably $\alpha$ $\check{\tau \eta}$ ), given the proximity of a rival feminine noun, vं puzzling clash of conflicting genders, where a neuter demonstrative pronoun (again $\tau 0 \hat{\imath} \tau$ ) is followed by a feminine participle ( $\gamma \varepsilon v o \mu \varepsilon ́ v \eta)$, see Enn. V 2 [11] 1.16-17, a sentence whose daunting complexity has driven many editors to have recourse to emendation. The relation of the demonstrative pronoun to its antecedent in our two sentences is, by comparison, child's play.
} 
$\kappa \alpha i ̀ ~ \varepsilon ́ \kappa \theta \rho \varepsilon ́ \psi \alpha \nu \tau o \varsigma)$, to a pair of nouns (or nominal expressions) governed by a repeated preposition in the sentence following (1.16-17: $\dot{\varepsilon} v \sigma \omega ́ \mu \alpha \tau$ fol-

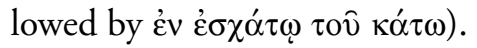

In the concluding words of the penultimate sentence (1.14-16), Plotinus has distinguished the 'receptacle' ( 'of', the object that is therefore 'contained within' or 'received by' the receptacle, namely 'the parent and feeder' ( genitive whose function is so obvious that it hardly needs a name, but that we may perhaps like to categorise as a genitive 'of possession' or 'of definition' (as in 'the Queen of England' or 'the author of Waverley').

When we are told, in the sentence following, the final sentence of the chapter (1.16-17), that one object is 'in' another, it is therefore 'the parent and feeder' that has to find itself 'in' the object designated as the receptacle (1.16-17). The sequence of thought can hardly be otherwise. If the genitive defines what is, linguistically, a spatial relationship, then for $A$ to be the 'receptacle of' $B$ cannot but entail that $B$ is 'in $A$ '. Whatever object has been specified as a 'receptacle' (1.15: $\dot{\pi} \pi \delta$ o $\chi \eta$ 'v) can be none other than the object 'in' which there is to be found whatever object has been specified by the noun, or nouns, in the genitive.

\section{Logic and syntax}

That simple logic and the even more simple syntax that goes with it determine the meaning of the passage as a whole. The object 'in' which the antecedent to the demonstrative pronoun is to be found, and the object

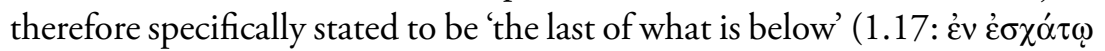

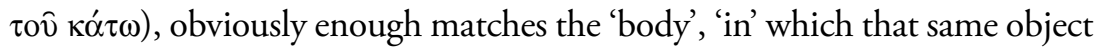
is to be found in the first part of the same sentence (1.16-17: '́c $\sigma \omega \dot{\mu} \mu \alpha \tau)$.

Both words have therefore to be taken as a description of the receptacle. The receptacle is both 'the last of what is below' and 'the body', in which there is to be found 'the parent and feeder', far and away the most obvious antecedent of the demonstrative pronoun (1.16: $\tau 0 \hat{\tau} \tau \mathrm{o})$. 'The parent and feeder', we might almost say, has been acting out of self-interest. The object that the parent has 'given birth to' and that the feeder has 'fed' is none other than the 'body' and the 'receptacle' in which that same 'parent and feeder' is to reside. 


\section{The choice of reading}

With that interpretation of the two sentences, the difference of reference

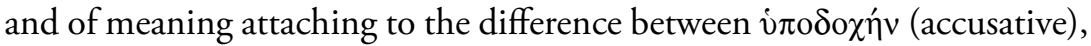
the unanimous reading of the manuscripts, and (nominative), Kirkhhoff's emendation, is minimal. Whichever reading we choose, the meaning required, in the context, is little different simply because, whichever antecedent we pluck out for $i \pi \circ \delta \circ \chi \eta \dot{v}$ or $\dot{v} \pi \circ \delta \circ \chi \eta$ from the words preceding

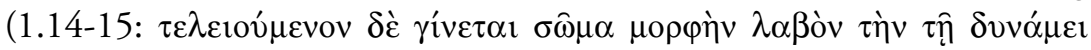

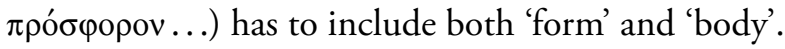

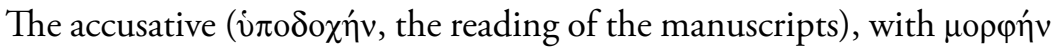
therefore as grammatically its antecedent, has to be understood as meaning that 'form', once it has been added to the object brought to birth by soul, so as to constitute a 'body', acts as the receptacle. The nominative ( $\dot{\pi} \mathrm{o} \delta \mathrm{\alpha} \chi$ ', Kirkhhoff's emendation), with $\sigma \hat{\omega} \mu \alpha$ as grammatically its antecedent, has to be understood as meaning that 'body' provides the receptacle, but only because what is said to be 'body' has 'become' so (cf. 1.14-15:

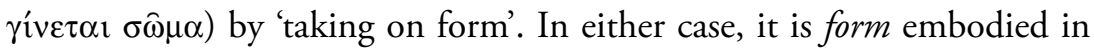
matter, or matter defined by form, and neither matter nor form alone, that constitutes the 'receptacle'.

With so minimal a difference of meaning, my own preference is to do as Henry has done, in the editio maior, and therefore to keep to the reading

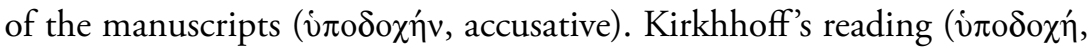
nominative), adopted by Schwyzer in the editio minor, may be right. But with no manuscript support, its insertion in the text is unduly intrusive.

\section{Body and soul}

With no need for any emendation of the unanimous reading of the manuscripts, we arrive therefore at the meaning given to the two sentences in the opening paragraphs of this section, the meaning required by both syntax

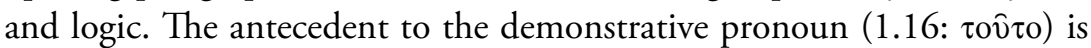
'the parent and feeder', which, in finding itself 'in body' and therefore 'in the last of what is below', finds itself in the receptacle that it has fashioned for itself, by first 'giving birth' to what is 'utterly indefinite' and then 'feeding' that same object with form, so constituting the receptacle-cum-body in which it now resides. 'Body' is therefore the 'receptacle' of soul...

Hardly a surprising conclusion, in a Plotinian universe, despite Plotinus' occasionally choosing, for ideological reasons, to reverse the relationship, 
and have body immersed in soul, as he does in a famous passage where body is compared to a net floating in the sea, with the sea representing the soul 'bearing up' or 'carrying' the body that is 'in' it. ${ }^{75}$

But even that image is less of an exception than it may seem. The elaborate metaphor gains its force precisely from being a reversal of the conventional representation, whereby soul is in body, not body in soul. Again (see $\$ 20$ above), we are not to look for an artificial consistency when Plotinus shifts from one image to another, over the years. 'Body' is the 'receptacle' of soul, and soul is therefore 'in body' in On the daimon. Body will be 'in soul' in the treatise written some years later. ${ }^{76}$

It is hardly surprising that the more conventional view has been adopted in On the daimon. Originality, in the concluding sentences of the opening chapter, would be misplaced. It is not the conclusion to his argument that Plotinus wants to insist on here; the novelty in his thesis turns on the 'events' (the logical 'events') that lead up to the conclusion. The demonstration is new. The demonstrandum, we might almost say, is taken for granted.

In the circle of Plotinus' friends and students, no-one would have been surprised to learn that 'body' is a 'receptacle' for soul, as much for the soul to be found in trees and plants as for the souls to be found in men and women. What would have been novel, and even disturbingly novel, would have been Plotinus' account of the 'events' leading up to so conventional a conclusion. Soul is 'in body' because soul has herself 'fed' with the form of body the object, initially utterly lacking in form, that she herself has 'brought to birth' (On the daimon) — the 'non-being' that she herself has 'made' (Various investigations).

\section{The rhetorical flourish}

Such is the background to the syntax and the logic that determine the meaning of the two concluding sentences of the opening chapter of On the daimon. The final sentence (1.16-17) is a deliberately simple summary of the state of affairs resulting from the events described in the

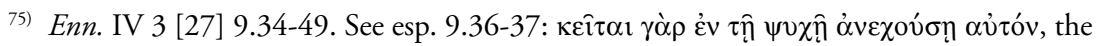
object portrayed as the body of the world 'lies within the soul that bears it up'.

76) The two passages compared are Enn. III 4 [15] 1.16-17, where soul is 'in body', and Enn. IV 3 [27] 9.36-37, where body is 'in soul'.
} 
sentences preceding (the whole of the opening chapter of On the daimon). The soul, specifically the soul that 'comes to be in plants', 'gives birth' to something that is 'utterly other than herself' and therefore 'utterly indefinite'. That same object is 'completed' by being 'nourished' and therefore acquiring the 'form' by which it 'becomes body'.

At the equivalent moment in the sequence of events described in Various investigations, the soul enters into the object that she 'makes' and has 'covered with form' (3.15-16). So too in On the daimon. The 'parent' and 'feeder', in the context hardly more than a periphrasis for soul, takes possession of the object which, thanks to its acquisition of form, has been made ready for her, and finds herself therefore 'in body' (1.16-17:

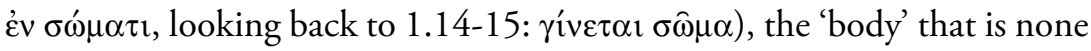
other than the 'receptacle' that soul has prepared for herself by the (logically) successive actions of 'giving birth' and of 'feeding'.

The rhetorical flourish, the repeated use of "̌ $\sigma \chi \alpha \tau o \zeta$, first as a nominative, secondly as a dative, joined to the opposition between 'above' and 'below', is almost to be heard as Plotinus' way of signing off this brief account of the final stages in the process of emanation. The soul, specifically the soul that finds herself in plants, is obviously enough 'the last of things that are above', i.e. the last representative of the higher realities. The receptacle provided for her, 'in' which she finds herself, is 'the last of what is below', matter therefore, but more specifically matter that has been endowed with the form of body, for only once it has been established as 'body' can the object that had initially been 'utterly indefinite' provide a suitable dwelling place, a 'receptacle', for the soul whose 'offspring' it has been said to be.

\section{$\$ 24$. The Soul's Two 'Makings'}

\section{'Feelings'}

Do I need to add that the conclusion of the preceding section has nothing whatever to do with my personal 'feelings', as Phillips seems to think it has? ${ }^{77}$ If this is not a mere slipshod use of the word, it betrays an approach to the text of the Enneads that is totally alien to my way of thinking, and that

\footnotetext{
77) See Phillips, 2009, 106: O'Brien 'feels...', followed by Phillips' summary of my account of Various investigations and On the daimon.
} 
I would regard as deleterious to any serious study of the philosophy of Plotinus. My 'feelings' in the matter have nothing to do with my attempts at determining the meaning of the text, and I can only hope that Phillips has been as successful as I aim to have been in keeping his personal 'feelings' at bay in his reconstruction and interpretation of what it is that Plotinus has to say.

Here, as in the publications that Phillips has set himself to review and to criticise, my analysis is based on a detailed study of the syntax and on close attention to the sequence of thought and image. I do also take into account, in so far as I know how, Plotinus' style of writing and even his style of thinking. But my subjective 'feelings', positive or negative, relating to the author and to what he writes, are not something that I would wish to impose upon readers who share my interest in Plotinus, nor do they have any relevance to what I claim to have established as the probable meaning of the text. If Phillips thinks otherwise, if he suspects that my interpretation of the text of the Enneads stems from, or has even been coloured by, my 'feelings', he is, I do very much hope, entirely mistaken.

\section{A less austere approach?}

Does Phillips perhaps have a less austere approach to the text? Is it possibly because he has let himself be guided by what he supposes to be a 'feeling' for the text of the Enneads that he is so much adrift in his attempted synthesis of individual passages?

Read again, if you still have the patience, Phillips' jumbled comparisons on the last-but-one full page of his article. Phillips claims that the word '̌ $\propto \alpha \alpha \tau \varsigma$, 'last', to be found in his leading passage from On contemplation, where it is attached to the description of the 'corpse-like' logos related to 'visible form', has the same reference as the first occurrence of the word in the final flourish of the opening chapter of On the daimon. ${ }^{78}$

\footnotetext{
78) For the use of "̌ $\chi \alpha \alpha \tau \varsigma$ in On contemplation, see $\$ 5$ above (Enn. III 8 [30] 2.30-32:

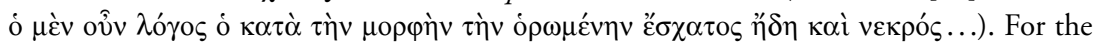
use of the same word in On the daimon, see the passage already quoted (Enn. III 4 [15]

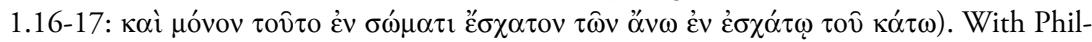
lips' reading of the texts, 2009, 107 and 134, the first of the two occurrences of है $\sigma \alpha \alpha \tau$ in

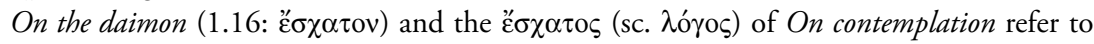
one and the same entity.
} 
Once we have correctly identified the first occurrence of है $\sigma \chi \alpha \tau o \varsigma$ in $O n$

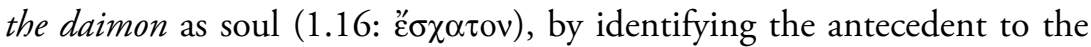

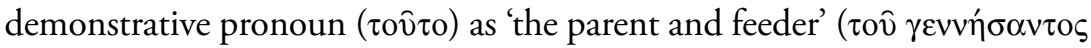

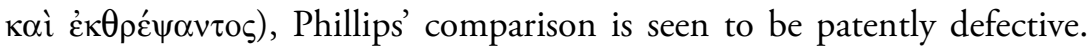
No soul, however lowly, is a 'corpse', as is the logos of On contemplation. 'The last of things that are above' is admittedly the lowest manifestation of soul, soul 'when she comes to be in plants', but it is a soul nonethelessa soul and not a 'corpse'.

Even were Phillips to attempt to correct his comparison, by aligning the

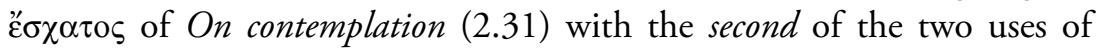

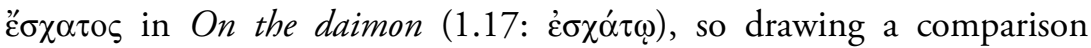
between the logos that is, or that is associated with, 'visible form' (On contemplation) and 'the last of what is below' and therefore 'body' (On the daimon), he would still have fallen short of his purpose. For underlying the 'visible form' of On contemplation, there is the 'substrate' (2.30), and prior to the establishment of 'body', in On the daimon, is the object that is 'utterly indefinite' (1.13-14). 'Body' therefore, though it can be presented, thanks to its conjunction with matter, as 'the last of what is below', is not directly the object, said to be 'utterly indefinite', 'brought to birth' by soul, nor therefore is it the object that I claim to be matter.

If the 'corpse-like' logos of On contemplation is to be found a place in the opening chapter of On the daimon, it can be no more than the instrument by which the soul that 'comes to be in plants', and that is therefore 'the last of things that are above', effects the 'nourishment' of the object that she has brought to birth, so making for herself a receptacle, the 'body', that is here counted as 'the last of what is below'. It is the object that the soul is said to have 'brought to birth' (1.6: $\gamma \varepsilon v v \hat{\alpha}, 1.16: \gamma \varepsilon v v \eta ́ \sigma \alpha v \tau o \varsigma)$ that I claim to be directly comparable to the object 'made' by soul in Various investigations (3.10: $\pi \mathrm{ol \varepsilon} \hat{\imath})$, not that same object once it has been 'nourished' and therefore converted into 'body' by its acquisition of form (1.14-16).

\section{The soul's two 'offspring' and two 'makings'}

If that distinction proves too subtle for his grasp, it is because Phillips, perhaps governed more by 'feeling' than by thought, has adopted an all too simple-minded approach to the use of word and image in the Enneads, and has therefore failed to appreciate that Plotinus gives a significantly different reference and meaning to talk of 'making' and of an 'offspring' 
when writing of the soul's relationship with the sensible world in different treatises, not least in treatises separated by a gap of years, rather than months. ${ }^{79}$

Soul 'makes' in Various investigations (3.10: $\pi \mathrm{ol \varepsilon î})$, and she 'makes'

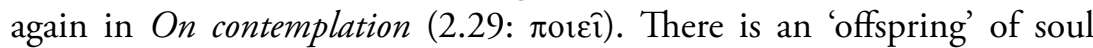
in On contemplation (2.29: $\gamma \varepsilon \dot{\varepsilon} v \eta \mu \alpha)$ and an equivalent expression, again

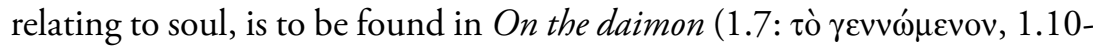

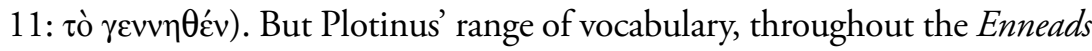
and especially when making play with what are manifestly images or metaphors ('giving birth to', 'feeding', 'corpse-like' ...), is not extensive, and the repetition of the same, or virtually the same, word need not imply an identity of meaning and reference, independently of the context.

The two 'makings', in Various investigations and in On contemplation, are not therefore to be taken as necessarily designating the same activity. Nor is the repetition of virtually the same expression for the product of soul,

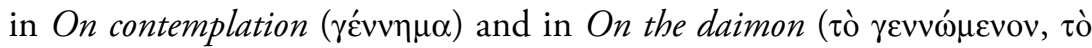
$\gamma \varepsilon v v \eta \theta \dot{\varepsilon} v)$, any guarantee that the object referred to is therefore the same in the two treatises.

\section{An unbridgeable gap}

So much is, or should be, obvious enough once we take account of the similarity between the objects described in Various investigations and in On the daimon and the radical difference with what is said of the object produced in On contemplation. The object that the soul 'gives birth' to in On the daimon is 'utterly indefinite' and lacking in form (1.10-14). Similarly the object that the soul 'makes' in Various investigations is 'indefinite' (3.12) and 'without logos' (3.13). Neither object can therefore be equated with the 'offspring' of soul in On contemplation, which is none other than

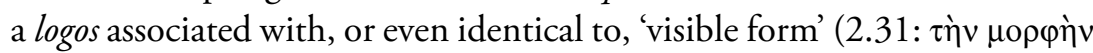

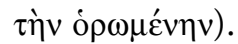

\footnotetext{
79) See $₫ 13$ above for the chronology of the three treatises that I shall here refer to. Various investigations, Enn. III 9 [13], and On the daimon, Enn. III 4 [15], both belong to the series of 21 treatises that Porphyry found already written when he arrived in Rome in 263 A.D. On contemplation, Enn. III 8 [30], falls roughly midway in the group of group of treatises that were written in the course of the six years that followed, the years that Porphyry spent with Plotinus before leaving for Sicily.
} 
The use of the same or virtually the same word for the offspring of soul,

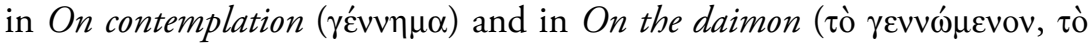
$\gamma \varepsilon v v \eta \theta \varepsilon$ ) ), does nothing to bridge that unbridgeable gap, nor even does the fact that the 'offspring' of soul in On contemplation is said to be a 'corpse' (2.32: veкрós) and that the offspring of soul in On the daimon is said to be 'lifeless' (1.7: ’ै $\zeta \omega v)$.

In supposing that it does, and therefore identifying the 'offspring' that is a 'corpse' in On contemplation with the 'lifeless' object that has been 'given birth to' in On the daimon, Phillips has not only failed to take account of the difference between the object that is a logos and the object that is entirely lacking in logos. He has also failed to see what is implied, and what is not implied, by the image of a 'corpse' in the Enneads. ${ }^{80}$

In On contemplation, as elsewhere in the Enneads, a 'corpse' is indeedhow could it not be?-deprived of life. But it is not therefore entirely deprived of form, unlike the object described as 'lifeless' in On the daimon. Dead - and therefore 'lifeless' - it may be, but a corpse is not therefore what we might perhaps think of as a shapeless mass, which is why the 'corpse' of On contemplation can be associated with, or even identified with, 'visible form', the form to be seen as the shapes and colours of the world around us, and that is entirely absent from the object described as 'lifeless' in On the daimon.

Much the same implication may be found attaching to the image of a 'corpse' when it appears elsewhere in the Enneads. The 'corpse' of The three principal hypostases is equated with the two lower elements of the universe, earth and water (2.26), again therefore not an unrecognizable mass, but a 'corpse' nonetheless, for so long as soul is absent from the world. So too, the 'corpse' of On matter, specifically said to be 'something definite'

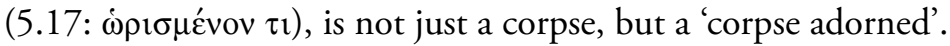

Simply because it is 'lifeless', the product of soul in On the daimon cannot therefore be construed, without more ado, as a corpse. At the moment of its production, it is 'utterly indefinite' and therefore cannot even be furnished with the form of 'body', much less with whatever specific bodily properties are required to produce the elements of earth and water (in

80) Phillips, 2009, 134, seemingly takes for granted that the object said to be 'lifeless' in On the daimon (1.7) is the same as the 'corpse' of On contemplation (2.32). 
The three principal hypostases), the 'adornment' of the 'corpse adorned' (in On matter).

\section{A possible synthesis}

That radical, and obvious, discrepancy cannot be tossed aside if we hope to arrive at a meaningful correlation of the texts where there is talk of 'making' and of an 'offspring'. We may well suppose that the 'visible form' that physis 'makes' in On contemplation is included in, or is subsequently added to, the 'form' that soul will give to the object that she has 'made' in Various investigations (cf. 3.15-16: غ̇ $\mu$ ó $\varphi \omega \sigma \varepsilon$ ). We may also suppose that it is included in, or added to, the 'form' (1.15: $\mu о р \varphi \eta v)$ that the 'offspring' of soul in On the daimon receives by way of 'nourishment' from its parent, the 'form' and the 'nourishment' by which what had initially been 'utterly indefinite' will be raised to the level of 'body'. But that correlation is incompatible with any simple one-to-one identification of soul's 'making' in Various investigations and her 'making' in On contemplation.

The two 'makings', the 'making' of Various investigations and the 'making' of On contemplation, are no more the same than the soul's two 'initiatives', as described or implied in Various investigations, are the same. When the soul 'makes' in Various investigations (3.10: $\pi$ otعî), the 'making' is an expression of her (implied) first initiative. The soul's 'making' in On contemplation (2.29: $\pi 01 \varepsilon \hat{\imath})$, if it is to be found a place in Various investigations, will be an expression of the soul's second (explicit) initiative

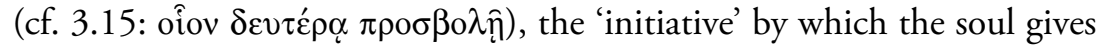
form to the object that she has already 'made' as a consequence of her (implied) first initiative.

What the soul 'makes' in Various investigations is alogos (3.13). The soul's 'making' in On contemplation is the 'making' of a logos (2.29-31), the logos therefore that is lacking in the object 'made' by soul in Various investigations, and that, if present at all in the earlier treatise, can be so only as included in, or added to, the form which soul brings to that same object in the course of a 'second', and subsequent, 'initiative'.

\section{'Lowest matter'?}

To arrive at even that simplest of simple syntheses, we have to keep closely to the syntax of the texts in question and to the sequence of thought that 
the syntax both requires and implies, and not rely, as Phillips has done, on simply heaping up repetitions of the same verb and the same image, independently of the obvious difference of context.

No less importantly, we have also to avoid tossing into our discussion concepts and categories that are nowhere to be found, stated or implied, in the text of the Enneads, however easily they may slip off the tongue or pen of the modern commentator. So it is when Phillips writes of 'lowest matter', a concept and a form of words that Phillips ascribes to myself, seemingly as equivalent to the second use of " $\sigma \alpha \alpha \tau$ os in the sentences quoted from On the daimon (1.17: $\dot{\varepsilon} \sigma \chi \alpha \dot{\tau} \tau$, in the dative). ${ }^{81}$

'Lowest matter' is a figment of Phillips' imagination. A 'lowest matter' is not recorded under any one of the fourteen divisions and subdivisions that Sleeman and Pollett have introduced to categorise the wide range of references to 'matter' in the Enneads. ${ }^{82}$ The word "̌ $\sigma \chi \alpha \tau$ ' a number of times in relation to matter. ${ }^{83}$ But never to describe a matter that would be the 'lowest' or the 'last' in relation to some other type or degree of matter.

As for Phillips' favourite victim, my unworthy self, I can only, once again, protest my innocence. Despite being expressly laid at my own door, the expression 'lowest matter' is not, so far as I can remember, an expression that I have ever adopted as my own. I am not even entirely sure of the meaning that would accrue, in such an expression, to the superlative ('lowest'). The underlying assumption is perhaps that intelligible matter is a 'higher' matter, that 'body' or 'receptacle' is counted as a 'lower' matter, and that what is 'utterly indefinite' is therefore a 'lowest matter'. So arcane and unwieldy a categorisation of the object produced by soul, with its unwonted but unavoidable implication that there is a plurality of 'matters'

81) Phillips, 2009, 107-108. 'Seemingly': I am said to have stated 'unconditionally' that 'lowest matter' designates the object said to be 'utter indefiniteness' and 'utterly indefinite'. If I have followed aright the sequence of thought in Phillips' cascading sentences (p. 107), I am also committed to a no less 'unconditional' use of the expression to cover 'the last of what is below', and therefore $\dot{\varepsilon} \sigma \chi \alpha \dot{\tau} \tau$, in the dative, in the same treatise (On the daimon, 1.17). I do write of a 'last stage' in the production of the sensible cosmos ( $\$ 14$ above) and of a 'lowest level' in the stratification of the visible world ( $\$ 15$ above). Neither expression implies the existence, in the sensible world, of more than one 'matter', nor therefore of a 'lowest' matter. See the continuation of my main text, above.

82) Sleeman and Pollet, 1980, s.v. v̈ $\lambda \eta$ (col. 1044.52-1055.34).

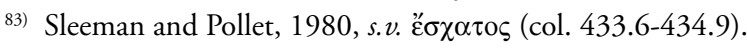


to be found in the sensible world, is not, I hope, one that I have ever ascribed to. ${ }^{84}$

\section{A sigh of disbelief}

But to pursue the confusions of word and thought that, here as elsewhere, go hand-in-hand with Phillips' misunderstandings of the Greek is a wearisome, and perhaps ultimately a profitless task. Leave aside the confusions of word and thought, correct the mistranslations, and the voice that speaks to us in the Enneads will be heard speaking both sanely and clearly-and nowhere more sanely and more clearly than in the opening chapter of On the daimon.

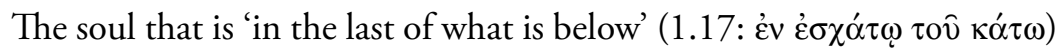

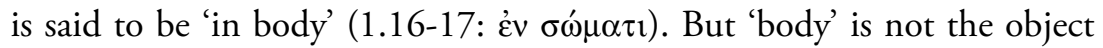
that first issues from the soul. The object that the soul of On the daimon first 'gives birth to' is 'utterly other' than the soul from which it derives

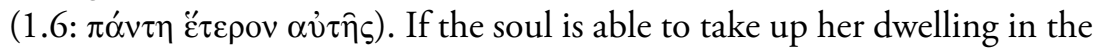
object to which she herself has given birth, it is only because what is 'utterly other' and 'utterly indefinite', the object to which the soul herself has given birth, has been 'completed' as a result of the soul's own subsequent activity. The soul first 'gives birth to' and then 'feeds' with form the object she has brought to birth. It is only once that same object has been 'fed' with the form of 'body' that it is able to act as a 'receptacle' for soul.

Those same events have their exact counterpart in Various investigations. In Various investigations, a 'partial soul' first 'makes' an object that is 'utterly dark'. Only when she has 'covered' that same object 'with form' does soul 'enter rejoicing' into the object that has been made ready to receive her.

Construed in this way, the two treatises, Various investigations and On the daimon, convey the same simple message. In both treatises, the argument has been built around a carefully constructed sequence, first soul's

\footnotetext{
84) If he thinks I have, may I ask Phillips to quote chapter and verse? It is really very odd that in attempting, as he does so often and at such length, to summarise my interpretation, Phillips persistently ascribes to me expressions and concepts that are not mine at all. For other flagrant examples of misquotation, see $\$ 4$ above and $\$ 35$ below. Since Philips has such difficulty in understanding my plain English (and my no less straightforward French), it is perhaps hardly surprising that he is so much at sea when tackling Plotinus' elliptical, and often contorted, Greek.
} 
'making' or 'giving birth', secondly soul's 'covering with form' and 'nourishing' the object so produced, and thirdly the soul's 'joyful entry' into the object, the 'receptacle', that thanks to the presence of form has been made ready for her habitation. That simple sequence, so I would claim, is how Plotinus, in the Enneads, has chosen to express his conception of the origin of matter and of the relation of matter to soul in the sensible world. The soul's initial 'making', her 'giving birth', is none other than a making of matter.

It is hardly surprising that Phillips does not agree. In the pages where he attempts to grapple with the same texts, the whole delicately woven story of the soul and her offspring has been torn to ribbons. Soul has been confused with the object that soul has 'made'. The parent has been confused with its 'offspring'. 'The last of things above' has been confused with 'the last of what is below'. Do I hear Plotinus heave a sigh of disbelief that his careful use of word and image should have been so sadly and so totally misunderstood?

\section{To be continued}

\section{Bibliography}

Armstrong, A. H. 1967. Plotinus, with an English Translation, vol. iii, Enneads (sic) III 1-9. London: W. Heinemann. Cambridge, Massachusetts: Harvard University Press.

Chantraine, P. 1968. Dictionaire Étymologique de la Langue Grecque, Histoire des Mots. Paris: Klincksieck.

Denniston, J. D. 1966. The Greek Particles, 2nd edn (1954), reprinted 'with corrections'. Oxford: Oxford University Press.

Des Places, É. 1929. Études sur Quelques Particules de Liaison chez Platon. Paris: Les Belles Lettres.

Goulet, R. 1982. 'Le Système Chronologique de la Vie de Plotin', in L. Brisson, M.-O. GouletCazé, R. Goulet, D. O’Brien, Porphyre, La Vie de Plotin, tome i, Travaux Préliminaires et Index Grec Complet, 187-227. Paris: Vrin.

Henry, P., Schwyzer, H.-R. (ed.). 1951. Plotini Opera, tomus I, editio maior. Paris: Desclée de Brouwer. Bruxelles: L'Édition Universelle.

—. 1964. Plotini Opera, tomus I, editio minor. Oxford: Clarendon Press.

Kirkhhoff, A. (ed.). 1856. Plotini Opera. Lipsiae: Teubner.

Liddell, H. G., Scott, R., Jones, H. S. 1940. A Greek-English Lexicon, 9th edn. Oxford: Clarendon Press. (Quoted as LSJ.) 
O'Brien, D. 1991. Plotinus on the Origin of Matter, An Exercise in the Interpretation of the 'Enneads'. Napoli: Bibliopolis.

— 1993. Théodicée Plotinienne, Théodicée Gnostique. Leiden / New York / Köln: E. J. Brill. 2005. 'Matière et Émanation dans les Ennéades de Plotin', in C. Viano (ed.), L'Alchimie et ses Racines Philosophiques, La Tradition Grecque et la Tradition Arabe, 63-87. Paris: Vrin.

Phillips, J. 2009. 'Plotinus on the Generation of Matter', The International Journal of the Platonic Tradition 3, 103-137.

Schwyzer, H.-R. 1951. 'Plotinos', Paulys Real-Encyclopädie der Classischen Altertumswissenschaft, Neue Bearbeitung, Band 21.1, col. 471-592.

Sleeman, J. H., and Pollet, G. 1980. Lexicon Plotinianum. Leiden: E. J. Brill. Leuven: University Press. 